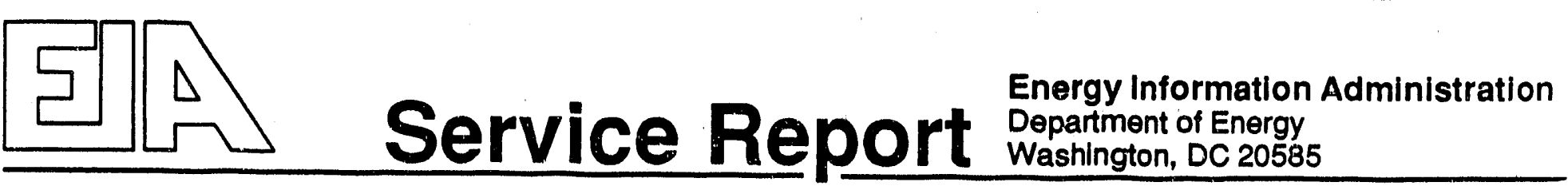

SR/EMEU/90-3

Implications of Lifting The Ban On The Export of Alaskan Crude 011:

Price and Trade Impacts

JUNE 1990

ENERGY INFORMATION ADMINTSTRATION

OFFICE OF ENERGY MARKETS AND END USE

U.S. DEPARTMENT OF ENERGY

WASHINGTON, DC 20585

Service Reports are prepared by EIA upori special request and may be based on assumptions specified by the requestor. Information regarding the request for this report is included in the Preface. 


\section{Implications of Lifting The Ban On The Export of Alaskan Crude 011: Price and Trade Impacts}

JUNE 1990

\section{DISCLAIMER}

This report was prepared as an account of work sponsored by an agency of the United States Government. Neither the United States Government nor any agency thereof, nor any of their employees, makes any warranty, express or implied, or assumes any legal liability or responsibility for the accuracy, completeness, or usefulness of any information, apparatus, product, or process disclosed, or represents that its use would not infringe privately owned rights. Reference herein to any specific commercial product, process, or service by trade name, trademark, manufacturer, or otherwise does not necessarily constitute or imply its endorsement, recommendation, or favoring by the United States Government or any agency thereof. The views and opinions of authors expressed herein do not necessarily state or reflect those of the United States Government or any agency thereof.

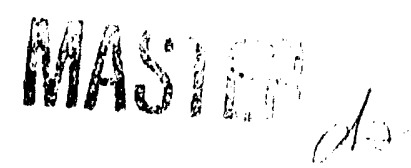

DISTRIBUTION OF THLS OOCUMENT IS UNLIMITER 


\section{CONTACTS}

This report was prepared by the International and Contingency Information Division (ICID) and the Economics and Statistics Division (ESD) within the Office of Energy Markets and End Use (EMEU). General questions concerning the contents of the report may be addressed to $\mathrm{W}$. Calvin Kilgore (202/586-1617), Director of EMEU; Mark E. Rodekohr (202/586-1130), Director of ICID; Derriel B. Cato (202/586-6574), Chlef of the Analysis Branch of ICID; or Mary E. Northup (202/586-1445), Chief of the Macro and Financial Information Branch of ESD.

Detalled questions concerning the contents of this report may be addressed to Dan Butler (202/586-9503), Phillip Tseng (202/586-1154) or Gerard Lagace (202/586-1452). 


\section{PREFACE}

The Energy Issues group of the United States General Accounting Office requested that the Energy Information Administration (EIA) analyze the implications of lifting the ban on the export if Alaskan crude o1i. This is EIA's second response to that request. The main objective of both reports is to estimate the potential Impacts on crude ofl and product prices as well as on petroleum trade flows. The quantitative results in the present report supersede those in the first since they are based on a more comprehensive modeling system. The first report addressed 1988 only and assessed the potentlal effects of lifting the ban on Alaskan exports on a region by region basis, but without the secondary effects of changes in one region on the situation in another region. The second report looks at both 1988 and 1995 and explicitly models the changes in trade flows that cause those secondary effects. 


\section{CONTENTS}

Page

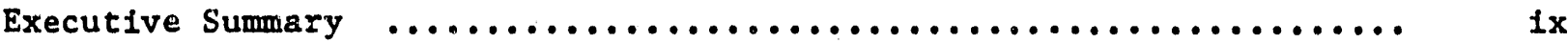

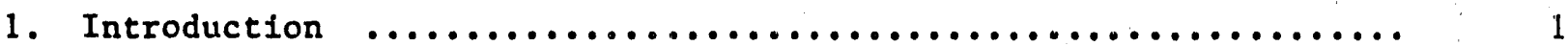

2. Factors Affecting the Trade Flow of Alaskan Crude $011 \ldots \ldots$

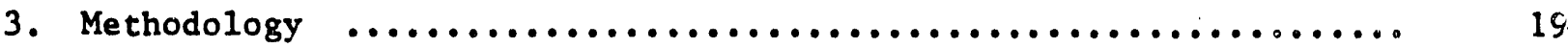

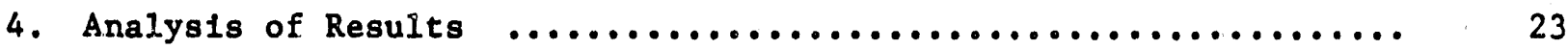

5. Limitations and Qualifications .........................4.

Tables

1. Demand for Refined Petroleum Products in Five Regions In 1988

2. Capacities for Key Refinery Processing UnIts In Five Major Reglons in 1988

3. Types of Crude 011 Uised In Four Foreign Regional Refineries

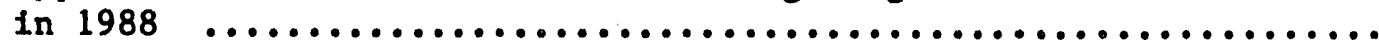

4. Alaskan North Slope Crude 011 Assay ......................... 14

5. Tanker Rates for Alaskan Crude 011 from Valdez to Varlous Ports by Type of Carrier in $1988 \ldots \ldots \ldots \ldots \ldots \ldots \ldots \ldots \ldots \ldots \ldots \ldots \ldots \ldots$

6. West Coast Price-Quant1ty Relationships for ANS Crude 011 at Var1ous Export Leve18, 1988 and 1995

7. Changes in ANS Crude 011 Shipments to Domest1c Outlets in 1988 and 1995 Resulting from Constralned and Unconstrained Exports of ANS Crude $011 \ldots \ldots \ldots \ldots \ldots \ldots \ldots \ldots \ldots \ldots \ldots \ldots \ldots \ldots \ldots \ldots$

8. Increases in West Coast Refinery Acquisition Costs of Crude 011 Produced In that Area at Various Export Levels, 1988 and 1995 ... 
9. Changes in U.S. Crude 011 Exports and Imports in 1988 and 1995 Resulting from Constrained and Unconstralned Exports of ANS Crude 011 ........................................

10. Changes in West Coast Refinery Acquisition Cost of Crude 011 from Domestic and Forelgn Sources, by ANS Export Level, 1988

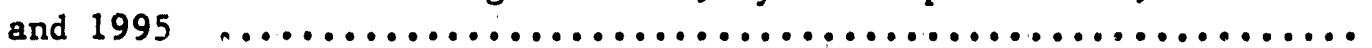

11. West Coast Refinery Gate Product Prices at Various ANS Export

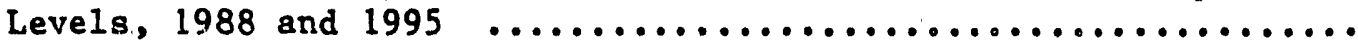

12. Changes in Petroleum Product Imports Into the West Coast at Varlous ANS Crude 011 Export Levels, by Type of Product, 1988

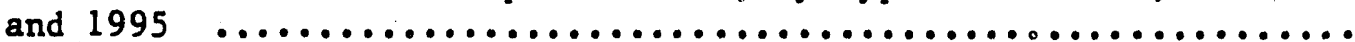

13. Changes in Petroleum Product Exports from the West Coast at Varlous ANS Crude 011 Export Lévels, by Type of Product, 1988 and 1995

14. Petroleum Supply and Demand Balances on the West Coast at Vartous ANS Export Levels, 1988 and 1995

\section{Figures}

1. Comparison of Demand Shares of Refined Products in Five Regions 1n 1988

2. Comparison of Distillation Capacities in Five Regions in 1988

3. Comparison of Cracking Capacities in Five Reglons In $1988 \quad \ldots \ldots \ldots \ldots \ldots \ldots \ldots \ldots \ldots \ldots \ldots \ldots \ldots \ldots \ldots \ldots \ldots \ldots \ldots \ldots \ldots$

4. Comparison of Major Hydrotreating Capacities in Five Regions

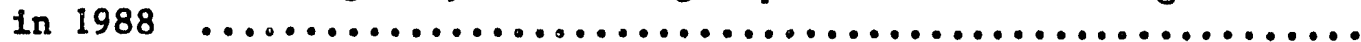

5. Marine Transportation Rates for Crude 011 from Valdez, Alaska

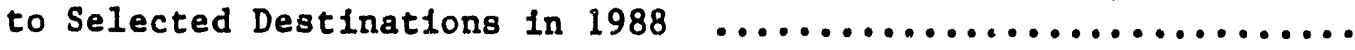

6. West Coast Price-Quantity Relationships for ANS Crude 011 at Varlous Export Levels in 1988 ...........................

7. West Coast Price-Quantity Relationships for ANS Crude 011 at Various Export Levels, Projected 1995

8. Changes in Product Imports on the West Coast at Vartous ANS Export Levels in 1988 
9. Changes in Product Imports on the West Coast at Various ANS Export Leve1s, Profected 1995

10. Changes in Product Exports from the West Coast at Varfous ANS Export Levels in $1988 \ldots \ldots \ldots \ldots \ldots \ldots \ldots \ldots \ldots \ldots \ldots \ldots \ldots \ldots \ldots$

11. Changes in Product Exports from the West Coast at: Varlous ANS Export Leve1s, Profected 1995 
EXECUTIVE SUMMARY

This study addresses the issue of the ban on exports of Alaskan crude oil. At present almost all crude ofl production from Alaska must be sold in the United States, 1.e., it may not be exported. Th1s study examines the impact, mainly on the West Coast, of eliminating this export restraint. The study concentrates on two time perlods. These are 1988, the most recent year for which complete data are available, and 1995, a year in which Alaskan production is profected to be substantially less than at present.

This is the Energy Information Administration's (EIA's) second report on this subject. The first was released earlier in 1990. They differ principally in the years for which results are presented and in the models used to generate quantitative results. The first report was 1imited to 1988 . The quantitative results for that year were based on use of a single region model and therefore did not take into account petroleum interactions among all areas of the world. Because of this Iimitation, quantitative results were limited to Alaskan crude oll prices. All other price and trade flow results were qualitative. In contrast, the present report covers both 1988 and 1995 . The quantitative results are generated with use of a more comprehensive model, one which does take Into account petroleum interactions among all areas of the world. The model-generated results cover both crude and product prices as well as petroleum trade flows. The quantitative results in the present report therefore supersede those in the first, although both sets are generally consistent.

The major conclustons of this analysis are:

- In both 1988 and 1995, substantial volumes of Alaskan o11 would be exported if the ban were lifted, because the refinery yleld pattern (1.e., percent gasoline, distillate, etc.) from Alaskan ofl is better suited for Far East markets than for the West Coast. More Alaskan o1l would have been exported in 1988 than in 1995 because Alaskan production was much higher in the earlier year than it is expected to be In the latter year.

- If exports were allowed, then the price of Alaskan oil would Increase due to 1 ts greater economic value in Far East markets. In both 1988 and 1995, this price Increase could amount to about $\$ 0.25$ per barrel if exports were restricted to 400 thousand barrels per day. In 1988 this price Increase might have been in excess of $\$ 2.00$ per barrel if exports had been completely unrestrained, a highly unlikely situation because of institutional relationships. 
- Although crude oll prices could increase, it is unlikely that petroleum product prices would show much of an increase because these products are traded in a competitive market and because higher crude oll costs could be offset by lower processing costs.

- If the export ban were eliminated, it is 11kely that Alaskan o11 would be expurted to Japan and other Asian markets and that this ofl would be replaced by Imports from Latin America, the Middle East (especially from the United Arab EmIrates and Qatar) and Malaysia.

It is difficult to establish the exact volumes of Alaskan crude ofl that would be exported. At a minimum, the more than 300 thousand barrels per day of o1l that was delivered to the U.S. Gulf and East Coasts would have been exported. At the h1gh end, much greater volumes, even in excess of the 500 thousand barrels per day not used on the West Coast, could have been exported due to the superior characteristics of Alaskan oil w1t regard to Far East market product demand. Long-standing institutional arrangements could potentially IImit the volumes imported by Far East markets;

The followirg tabulation shows the yleld pattern (o1l assay) of Alaskan oil compared to the demand slate for the Far East and West Coast markets.

Yield and Demand Patterns

Percent Gasoline

Alaskan 011 Yield

Far East Demand

West Coast Demand

$\begin{array}{rr}8 & 30 \\ 13 & 26 \\ 46 & 16\end{array}$

It is clear from these data that Alaskan o1l 1s better suited to the demand pattern of the Far East than to that of the West Coast, which has a very high demand for gasoline. It is this characterlstic that drives the results of this analysis.

Because of the export ban, Alaskan oil now sells at a depressed price or the West Coast. Currently, the price of Alaskan oll is determined by market forces on the Gulf Coast. However, by 1995, Alaskan oll should sell at near market prices even on the West Coast because much smaller volumes are expected to be produced.

If the ban were lifted, Alaskan oll could sell in markets where 1ts highest value would be realized. The amount of the price increase would likely be determined by the volume of oll actually exported, as shown below. 
Increase in the Price of Alaskan 011

(Constant 1988 Dollars per Barrel)

Maximum Allowable

Volume of Exports

$\underline{1988} \quad \underline{1995}$

$200 \mathrm{MB} / \mathrm{d}$

$\$ 0.15 \$ 0.13$

$400 \mathrm{MB} / \mathrm{d}$

0.25

0.19

$800 \mathrm{MB} / \mathrm{d}$

0.94

0.19

Unrestricted Exports

2.16

0.19

These estimates show that in both 1988 and 1995 the price increase would be similar for simflar export volumes, with the major difference being in the unrestricted case. In 1988 it is estimated that a much higher volume of Alaskan exports could have been fustifled on economic grounds than in 1995 because production 1s projected to decline dramatically by 1995 . Alaskan oil production is profected to fall from 2.0 million barrels per day in 1988 to 1.3 million barrels per day in 1995.

Even though crude oll prices could be expected to change as a result of lifting the ban on Alaskan exports, petroleum product prices are not expected to show a significant change (about 1 cent per gallon). This expectation is based on the fact that petroleum products are already traded on the world market and therefore are linked to world oil prices. In addition, if Alaskan oll were replaced by higher-cost crudes on the West Coast, these crudes would require less processing and therefore cost less to produce the needed volume of gasoline. Residual fuel prices are not expected to change much because residual fuel demand formerly satisfled by West Coast supply way be supplied hy sources in the international market.

World oll rrade patterns would be affected by the elimination of the export ban. It is estlmated that most of the exports of Alaskan oil would go to Japan and other Asian markets while this o11 would be replaced by imports from Latin America (mainly Mexico and Ecuador), the Middle East (such as the United Arab Emirates and Qatar), and Malaysia. Since the West Coast would be Importing crude olls better sulted for gasoline production than Alaskan ofl, gasoline Imports could have declined by between 50 to 100 thousand barrels per day In 1988 and by about 65 thousand barrels per day in 1995. However, product exports would also decline, leaving net product imports largely unchanged in both years. 


\section{INTRODUCTION}

Present legislation effectively bans the export of crude oll produced in the United States. The ban has been in effect for years and is particularly stringent with respect to crude oll produced in Alaska, particularly on the North Slope. The Alaska crude export ban is spectfically provided for in the Trans-Alaska Pipeline Authorization Act of 1973 and in other legislation. It was Imposed for two reasons. The first was to reduce U.S. dependence on Imported crude ofl. The Arab ofl embargo had been imposed shortly before the Act was passed and a greater measure of energy independence was considered imperative at that time. The second reason was to assure that funds expended in building an Alaskan pipeline would benefit domestic users rather than being simply employed to faclititate shipments to other countries.

The ban on exports of domestically produced crude oll is not total. Exceptions are permitted, but the conditions that must be met are stringent. Currently, only small quantities are exported. In 1988, for example, shipments from the United States and 1 ts territorles amounted to only 13 thousand barrels per day and were destined only for Canada and China/Talwan. Exports to the Chinal Taiwan area were from Alaska's Cook Inlet. Licenses to export crude ofl from parts of Alaska's Cook Inlet have been 1ssued since 1986.

The main objective of this report is to estimate the potential impacts on crude petroleum and petroleum product markets that would result from iff ing the export ban on Alaskan crude o11. The report focuses on Asian markets and

$1_{\text {Th1s }}$ is the second of two reports on this subject. The first was entitled Implications of Lifting the Ban on the Export of Alaskan Crude 011, SR/EMEU/90-1 (Washington, DC, March 1990). The Energy Information AdmInistration's (EIA's) Refinery Yleld Model (RYM) was used to generate results for the first report. The RYM results were restricted to Alaskan North Slope (ANS) crude ofl prices since that model is a single region model. The present report is based on results generated by a different EIA model, one which takes into account petroleum interactions among all areas of the world. Prices and shipment volumes are generated for both crude ofl and petroleum products for each of the world's refining reglons. The emphasis is on Alaska, the Weat Coast, and Japan since those are the areas that would be principally affected by the elimination of the $\mathrm{ba}_{\mathrm{i}}$ on the export of Alaskan crude o11. The model-generated results in the present report supersede those in the first even though both sets of results are generally consistent. 
the U.S. West Coast market, and on the export volume and price of Alaskan crude.

Section 2 describes the factors that would deteruine the trade flow of Alaskan crude oll if the export ban were abolished. These flows are determined by the demand for petroleum products in domestic and forelgn marketa, since the demand for crude oll is a derlved demand. The abllity of Alaskan crude oll to satisfy end-use demand, however, depends on the crude o11 assay of that ofl and the refinery configurations in various regions, particularly on the U.S. West Coast and In Japan.

Section 3 describes the methodology used to generate the results presented in this report, including the values for Alaskan crude o1l. The Energy Information Administration's (EIA's) Transportation and Refining of International Petroleum (TRIP) model was used to generate these values. TRIP is a linear programing model whose obfectlve function is to minimize the sum of all global resource costs. The model glmulates the worldwide refining environment, Including Japan and the U.S. West Coast, and takes as given the 1988 and 1995 values for product demand slates and refinery configurations in those areas and the characteristics of Alaskan North Slope (ANS) and other crude o11s.

Section 4 presents and analyzes the mode1-generated results and related data. The elimination of the export ban on Alaskan crude oll would I1kely cause substantial volumes of that crude to be exported and 1ts price to rise. The reason 1s that Alaskan crude ofl is better sulted to produce the middle distillate types of products required in the Pacific Basin than it is to produce the gasoline that is in heavy demand on the West Coast. The effects would have been greater if the ban had been eliminated in 1988 than they would be if it were eliminated 1n 1995. (The ban 18 assumed to be eliminated at the start of the year.) By the latter year, the continued decline in ANS crude oll production would cause the price of that crude to approach free-market prices even with the ban in effect. Exports of ANS crude oil could have ranged from 500 thousand barrels per day to 1.5 million barrels per day and prices of that crude could have increased by $\$ 0.50$ per barrel to over $\$ 2.00$ per barrel in 1988 if the ban had been eliminated in that year. In contrast, ANS crude exports would not 1ikely increase by more than 400 thousand barrels per day and prices of that crude by not more than $\$ 0.20$ per barrel if the ban were eliminated 1.n 1995. The exports would likely be directed to the Pacific Basin. Compensating volumes of crude would be Imported.

2 The term "West Coast," as used in this report, refers to Petroleum Administration for Defense District V (PADD V). PADD V consists of Alaska, Arizona, Calfíornia, Hawa11, Nevada, Oregon, and Washington. 
Product prices on the West Coust would not be greatly affected by the elimination of the ban. Trade in products is not subject to volume constraints and price changes are effectively limited by international prices and transport costs. Product prices on the West Coast, Including the prices of gasoline, could have fincreased by about 1 cent per gallon in 1988 and could even decrease by as much as 1 cent per gallon 1 n 19.35. The volume of gasoline imported into that area would decrease as refineries on the West Coast produce more gasoline with more suitable crudes. Exports of resldual fuel ofl from the West Coast would also decline as production of that product by refineries In that area decreases.

Section 5 discusses the limitatiors and qualifications of the analysis. They relate principally to the model, the sissumptions made, and the results generated. The principal limitation of the model is that all effects from eliminating the ban are instantaneously reflected in a new equilibrium solution. In reality, effects require time to be realized in the marketplace. Therefore, the effects generated by the model for years in which the ban is assumed to be eliminated may be overstated. The model also assumes that refinery capacity throughout the world is the same in 1995 as in 1988. This could affect processing costs, crude and product prices, and volumes traded. This Iimitation reflects the absence of adequate information on future changes in refinery configurations. Another limitation relates to world crude ofl productica, Including ANS production. O11 production is assumed to not vary when the ban is eliminated even though in reality ANS production could increase to some extent with higher prices. The effects of changing the assumed level of ANS production as well as modifying certain other assumptions is discussed. The results golerated by the model should be viewed in terms of general orders of magnitude wich could be roughly approximated over time if there were no offsetting factors rather than looked upon as highly accurate point estimates. 


\section{FACTORS AFFECTING THE TRADE FLOW OF ALASKAN CRUDE OIL}

Crude olls differ. Both the sulfur content and American Petroleum Institute (API) gravity of a specific type of crude oll partially determine its value. In addition, the first cut of one type of crude ofl (crude ofl assay) from a crude oil distillation unit affects its value; crude oils which produce intermediate products that require less prociessing to match end-use demand generally command higher prices.

To determine the demand for Alaskan ofl outside the United States requires that potential markets which value Alaskan ofl more highly than the price of that ofl on the U.S. West Coast be identified. That is, if the ban on the export of Alaskan crude were lifted, Alaskan crude would flow to foreign refining regions only if the offering prices for that crude in those regions were hIgher than on the U.S. West Coast.

Major factors that determine both domestic and foreign demand for Alaskan oil are as follows:

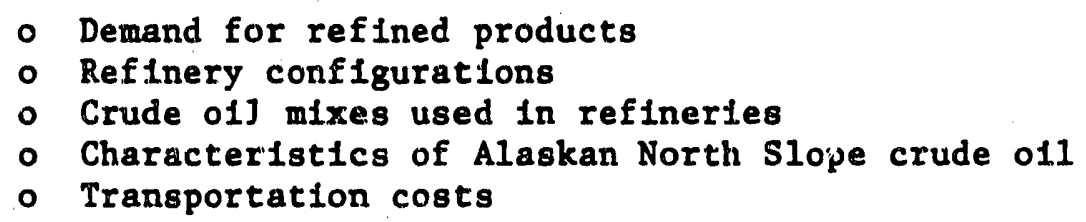

Potential markets for Alaskan crude oll are in the Pacific Basin because of its proximity to Alaska and the compatibility of refinery configurations and demand slates in that area with Alaskan crude ofl. For this reason, this analysis focuses on five major refining reglons: the U.S. West Coast, Japan, Southeast Asla (IImited to Brune1, Malaysia, Singapore, and Taiwan), Other Asla and Australla and New Zealand.

\section{Demand for Refined Products}

The demand for refined products in any region is determined by many factors. These include climate, geography, the soclo-economic structure of the region and its stage of economic development. Princtpally for these reasons, the composition of demand for refined products In Japan, Southeast Asla, and Other Asla differs sharply from that on the West Coast (Table 1 and Flgure 1). In 1988, for example, the gasoline share in the refined petroleum product market was less than 16 percent in Japan, less than 14 percent in Southeast Asia, and less than 10 percent in Other Asfa, but exceeded 45 percent on the West Coast. 
Table 1. Demand for Refined Petroleum Products in Five Reglons in 1988 (Demand in Thousands of Barrels per day; shares in percent)

\begin{tabular}{|c|c|c|c|c|c|c|c|c|c|c|}
\hline & \multicolumn{2}{|c|}{ West Coast } & \multicolumn{2}{|c|}{ Japan } & \multicolumn{2}{|c|}{ Southeast Asia } & \multicolumn{2}{|c|}{ Other As Ia } & \multicolumn{2}{|c|}{ Australla/NZ } \\
\hline & Dewand & $\begin{array}{l}\text { Market } \\
\text { Share }\end{array}$ & Demand & $\begin{array}{l}\text { Market } \\
\text { St.dre }\end{array}$ & Demand & $\begin{array}{l}\text { Market } \\
\text { Share }\end{array}$ & Demand & $\begin{array}{l}\text { Market } \\
\text { Share }\end{array}$ & Demand & $\begin{array}{l}\text { Market } \\
\text { Share }\end{array}$ \\
\hline Motor Gasoline & 1,251 & 46.4 & 677 & 15.5 & 131 & 13.7 & 278 & 9.5 & 328 & 42.8 \\
\hline Jet Fuel & 341 & 12.6 & 541 & 12.4 & 58 & 6.1 & 424 & 14.4 & 65 & 8.5 \\
\hline Distillate Fuel & 423 & 15.7 & 970 & 22.3 & 171 & 18.0 & 985 & 33.5 & 188 & 24.6 \\
\hline Res1dual Fuel & 268 & 9.9 & 851 & 19.5 & 407 & 42.9 & 734 & 25.0 & 48 & $6 . j$ \\
\hline $\begin{array}{l}\text { Liquifled Petro- } \\
\text { leum Gases }\end{array}$ & 68 & 2.5 & 536 & 12.3 & 51 & 5.4 & 179 & 6.1 & 46 & 6.0 \\
\hline Other & 348 & 12.9 & 783 & 18.0 & 132 & 13.9 & 339 & 11.5 & 90 & 11.7 \\
\hline Total & 2,699 & 100.0 & 4,358 & 100.0 & 950 & 100.0 & 2,939 & 100.0 & 766 & 100.0 \\
\hline
\end{tabular}

Note: Sum of components may not equal total due to independent rounding.

Sources: Energy Information Administration, Petroleum Supply Annual 1988, DOE/EIA-0340 (88/1) (Washington, DC, May 1989) and Organization for Economic Cooperation and Development, Quarter1y O11 and Gas Statistics, selected 1ssues. Estimates for non-OECD countries are based on ig87 demand patterns and estimated 1988 total demand.

The market share of residual fuel ofl was about 20 percent in Japan, 25 percent in Other Asla, and 43 percent in Southeast Asla, but less than 10 percent on the West Coast. The market share of distillate fuel on the West Coast was the smallest among all five reglons.

The significant differences in the demand for refined petroleum products Indicate that the demand for Alaskan oll may be very different in these five regions. New developments in the world petroleum market could contribute further to these differences. For example, Increased concern over environmental issues has led to tightened specifications for refined products and to the use of lower sulfur crude oll, such as Alaskan oll. On the other hand, Increased demand for gasoline tends to have a negative effect on the demand for Alaskan crude oll due to 1 ts low yleld in the gasoline range of products. However, the current market share for gasoline is relatively small in Japan, Southeast Asia, and Other Asia, compared with the West Coast. Therefore, a slightly higher demand for gasoline in the future may not reduce the competitiveness of Alaskan oil in these regions. 


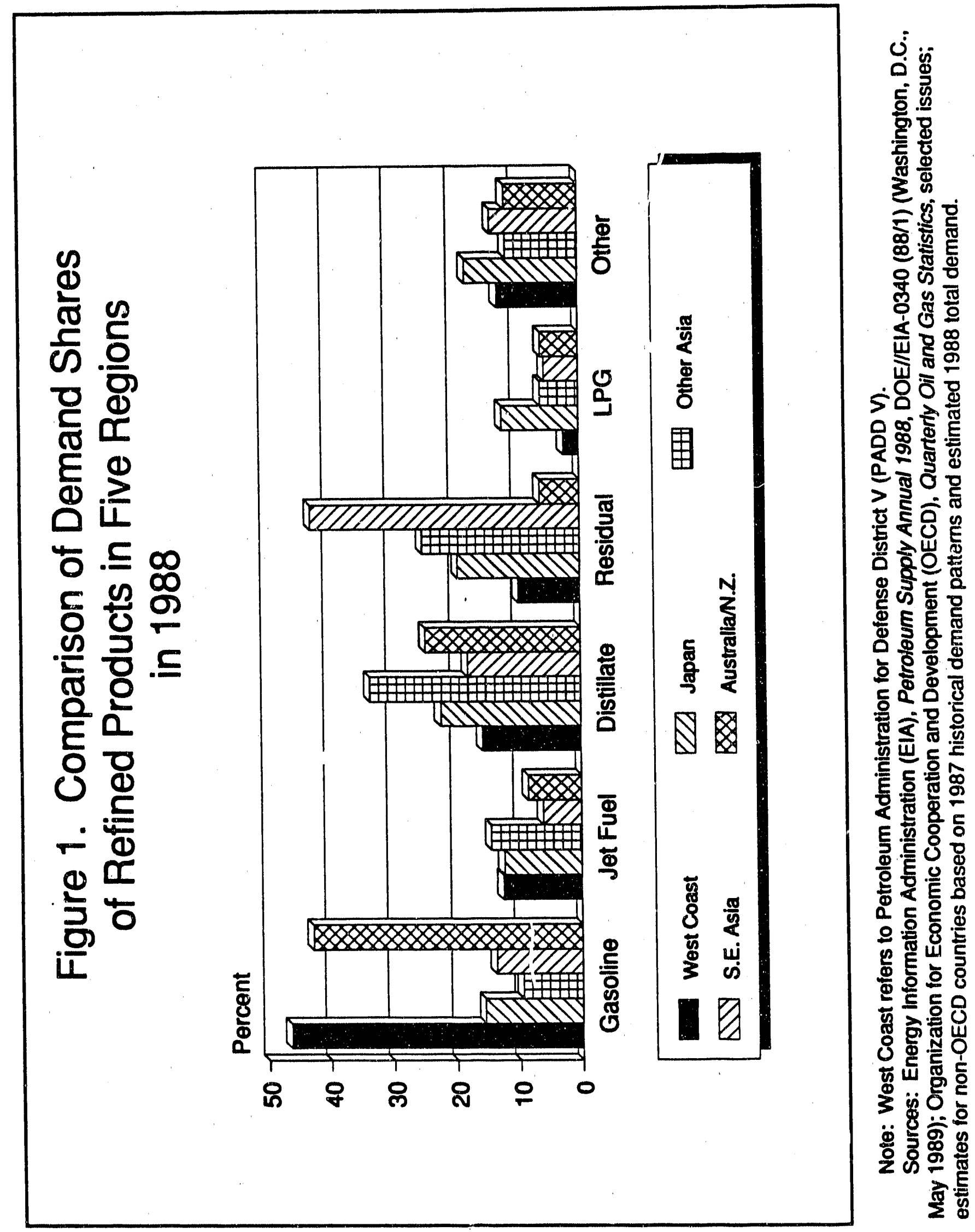




\section{R.efinery Configurations}

Table 2 and Figures 2, 3, and 4 compare capacttlel for key refinery processing uifts on the West Coast and in Japan, Southeast Asla, Other Asia, and Australla/New Zealand in 1988. The capacitles for these processing units reflect the effect of crude oil mixes that are most 11kely to be used in each region, the demand for refinec' products, and the configuration of the refineries in meeting indigenous or export demand for refined products. In general, cride ofl distillation capacities are closely correlated to the total demand for refined products in each region.

Table 2. Capacitles for Key Refinery Frocessing Units in Five Major Regions in 1988 (Thousand Barrels per Day)

\begin{tabular}{|c|c|c|c|c|c|}
\hline Processing Units & $\begin{array}{l}\text { West } \\
\text { Coast }\end{array}$ & Japan & $\begin{array}{c}\text { Southeast } \\
\text { Asia }\end{array}$ & $\begin{array}{l}\text { Other } \\
\text { Asta }\end{array}$ & $\begin{array}{c}\text { Australial } \\
\text { N.Z. }\end{array}$ \\
\hline $\begin{array}{l}\text { Crude Distillation } \\
\text { Vacuum Dist1llation } \\
\text { Coker-Delayed } \\
\text { Coker-Fluld } \\
\text { Vlscbreaker } \\
\text { Naphtha Hydrotreater } \\
\text { Distillate HDS } \\
\text { FCC Feed Hydrofiner } \\
\text { Resid Desulfurlzer } \\
\text { CAT Reformer High Pressure } \\
\text { CAT Reformer Low Pressure } \\
\text { Fluid CAT Cracker } \\
\text { Hydrocracker } \\
\text { Alkylation Plant }\end{array}$ & $\begin{array}{r}3,231 \\
1,649 \\
412 \\
110 \\
64 \\
573 \\
373 \\
490 \\
235 \\
384 \\
322 \\
773 \\
465 \\
146\end{array}$ & $\begin{array}{r}4,567 \\
1,676 \\
23 \\
0 \\
60 \\
850 \\
1,377 \\
208 \\
1,043 \\
476 \\
58 \\
557 \\
51 \\
11\end{array}$ & $\begin{array}{r}1,680 \\
387 \\
0 \\
0 \\
153 \\
219 \\
165 \\
137 \\
10 . \\
124 \\
14 \\
25 \\
68 \\
4\end{array}$ & $\begin{array}{r}2,927 \\
591 \\
26 \\
0 \\
211 \\
275 \\
193 \\
115 \\
51 \\
137 \\
71 \\
197 \\
11 \\
4\end{array}$ & $\begin{array}{r}719 \\
218 \\
0 \\
0 \\
0 \\
105 \\
192 \\
11 \\
17 \\
157 \\
2 \\
185 \\
20 \\
33\end{array}$ \\
\hline
\end{tabular}

Sources: Energy Information Administration, Petroleum Supply Annual 1988, DOE/E IA-0340(88/1) (WashIngton, DC, May 1989), and 011 and Gas Journal, December 28, 1987.

Two major categorles of processing units stand out in the comparison. The first cracks the heavy end of a barrel to lighter products and the second removes sulfur from the products.

Cracking capacitles were substantlally greater on the West Coast than in the other four regions in 1988. On the West Coast, capacitier for Cokers, Hydrocrackers, and Fluid Catalytic Crackers were 522 thousand barrels per day, 


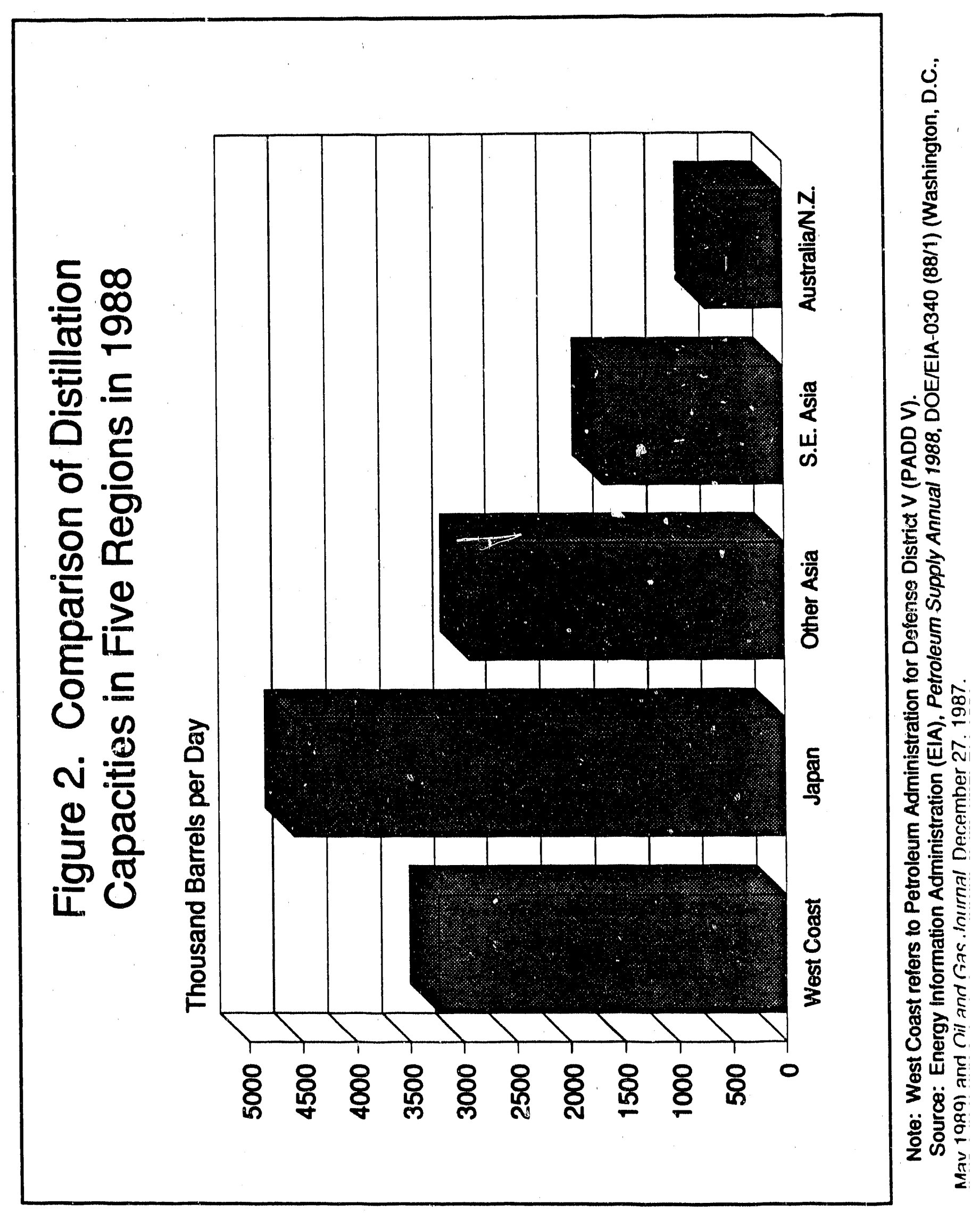




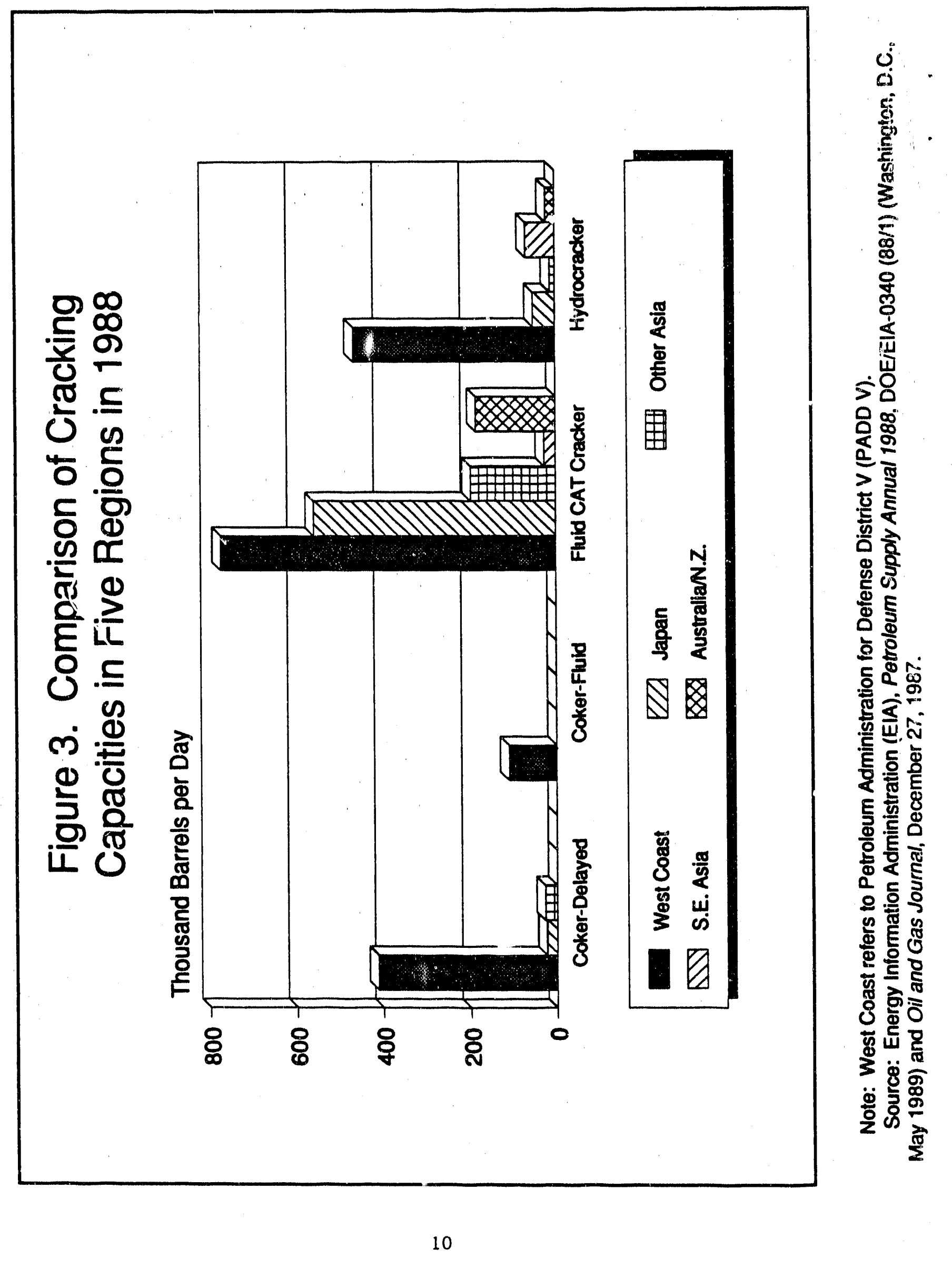



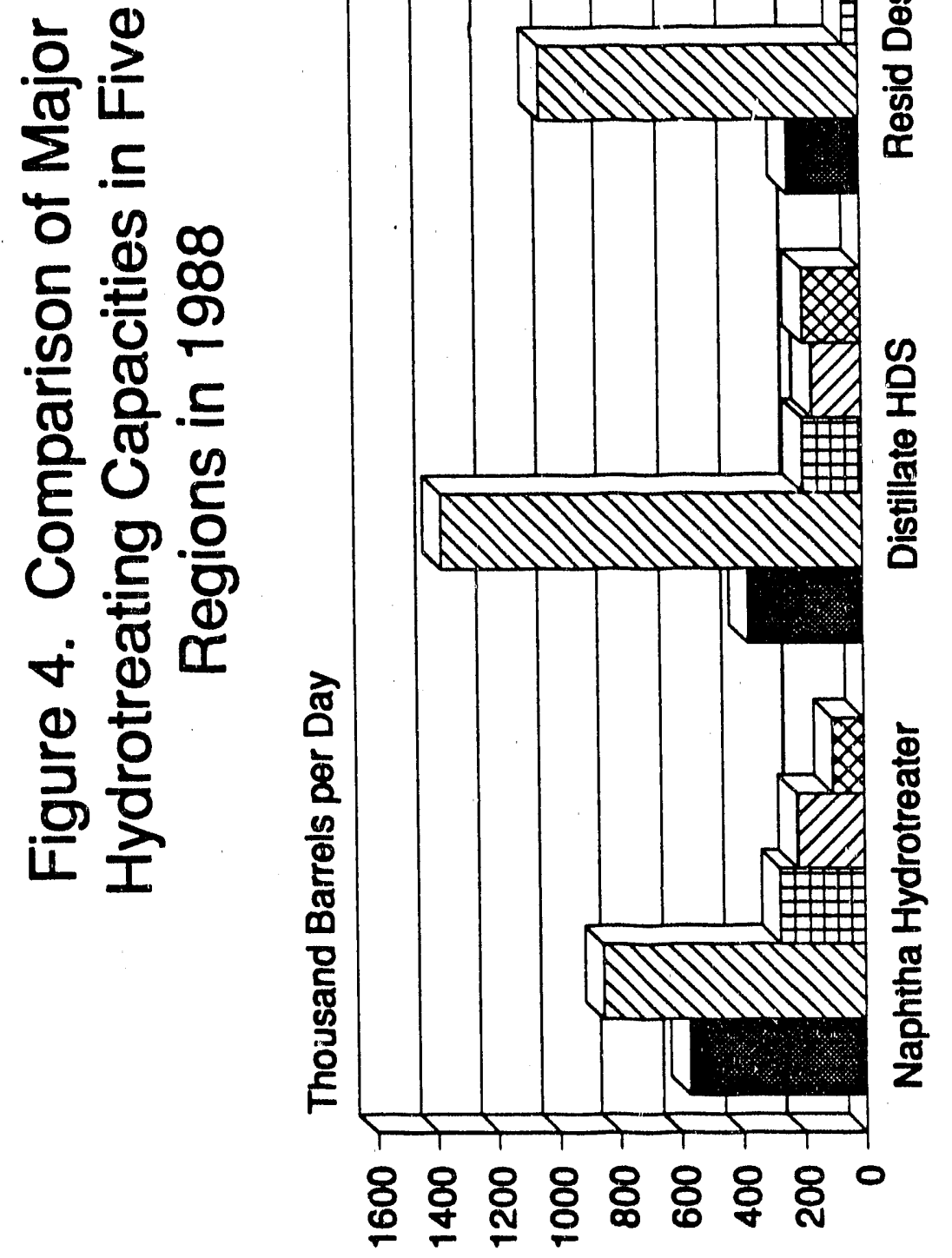

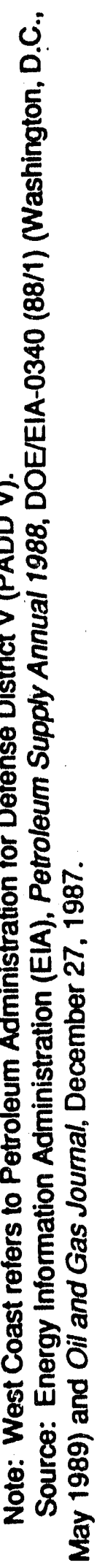


465 thousand barrels per day, and 773 thousand barrels per day, respectively, in 1988. A Coker converts asphalt or residual fuel oll to intermediate products to be processed in either a Fluld Catalytic Cracker or a Hydrocre iker. A Hydrucracker converts higher bolling point petroleum materfals such as aromatic cycle olls and coker distillates into gasoline and jet fuels. A Fluid Catalytic Cracker converts heavy olls into gasoline and lighter products. The greater cracking capacity for these conversion units on the West Coast than In Jipan and other Paclfic Rim countrles reflects the effect of much greater market demand for gasoline and much heavler crude ofl mixes on the West Coast with respect to the requirement to convert the heavy-end of a barrel into 11ghter products.

In contrast, hydrotreating units in Japan have a much greater capacity than those on the West Coast and uther Pacific Rim refining reglons. In Japan, capacities for Naphtha Hydrotreaters, Dist1llate Hydro-Desulfurlzers, and Residual Fuel Desulfurizers ware 850 thousand barrels per day, 1,377 thousand barrels per day, and 1,043 thousand barrels per day, respectively in 1988 .

The differences in the capacities of desulfurization units between the West Coast and Japan reflect the greater Japanese demand for naphtha, distillate fuel o1l, and residual fuel o1l, and environmental restrictions on the sulfur content of these fuels.

\section{Crude 011 Mixes Used In Refineries}

Given the demand for end-use petroleum products and refinery conflgurations, the output of refined products and the efficiency of refinery operations depend largely on the quality and volume of crude streams available to a refinery. The optimal crude o1l mix would include crude o1ls with sulfur content, API gravity and crude oll assuy that are best uluted for processing In a given refinery and that minimize the cost of meetirig a particular mix of petroleum demand.

In 1988, the four forelgn refining reglons processed the types of crude ofls shown In Table 3. In general, the API gravity of these crudes are higher than $27^{\circ}$, and the sulfur content of most of them are greater than 1.5 percent by welght, except crude olls from Algerla, China, Ecuador, Indonesla, Malaysia, Nigeria, and Norway. On average, these forelgn crude ofls are better gasoline producers than those indigenous crudes used on the West Coast. However, the capability of these 11ghter olls to produce lighter products such as gasoline is not fully utilized in regtons such as Japan, Southeast Asia and Other Asla due to the relatively low demand for gasoline and the much higher demand for distillate fuel and restdual fuel in those areas.

The West Coast Imported about 200 thousand barrels of crude o11 per day in 1988. The remalning crude o11 used in that area was Indigenous West Coast production, which included about 1.4 million barrels per day of crude from Alaska. The average API gravity of the crude used by the West. Coast refinerles was lower (heavier) than for those used in the four foreign refining reglons. 
Table 3. Types of Crude 011 Used In Four Forelgn Regional Refineries in 1988

\begin{tabular}{|c|c|c|c|c|}
\hline & Japan & $\begin{array}{l}\text { S-utheast } \\
\text { Asia }\end{array}$ & $\begin{array}{l}\text { Other } \\
\text { Asta }\end{array}$ & $\begin{array}{c}\text { Australia/ } \\
\text { N.z. }\end{array}$ \\
\hline Algerla & & $\mathrm{X}$ & $\mathrm{x}$ & \\
\hline Australia & $\mathrm{x}$ & $x$ & $x$ & $\mathrm{x}$ \\
\hline Canada & $\mathbf{X}$ & $\mathrm{x}$ & $\mathrm{X}$ & $\mathrm{X}$ \\
\hline China & $\mathrm{x}$ & $\mathrm{X}$ & $\mathrm{X}$ & \\
\hline Ecuador & & & $\mathrm{X}$ & \\
\hline Egypt & $\mathrm{X}$ & $x$ & $\mathrm{X}$ & \\
\hline Indonesia & $\mathrm{X}$ & $\mathrm{X}$ & $x$ & $\mathrm{x}$ \\
\hline Iran Heavy & $\mathrm{X}$ & $\mathrm{X}$ & $\mathbf{X}$ & $x$ \\
\hline Iran L1ght & $x$ & $\mathrm{X}$ & $\mathrm{X}$ & $\mathrm{X}$ \\
\hline Iraq & $x$ & $\mathbf{x}$ & $\mathrm{X}$ & \\
\hline Kuwa1t & $\mathrm{X}$ & & & $\mathrm{X}$ \\
\hline Malaysia & $x$ & $\mathrm{x}$ & $\mathrm{X}$ & $\mathrm{x}$ \\
\hline Mexico & $\mathrm{x}$ & $\mathbf{x}$ & $\mathbb{X}$ & \\
\hline Nigeria & & $\mathbf{X}$ & $\mathrm{X}$ & \\
\hline Norway & & $\mathrm{x}$ & $x$ & \\
\hline Saudi Heavy & $\mathrm{x}$ & $\mathrm{x}$ & $\mathrm{x}$ & $\mathrm{x}$ \\
\hline Saud1 LIght & $\mathbf{x}$ & $\mathrm{X}$ & $\mathrm{X}$ & $\mathrm{x}$ \\
\hline USSR & $\mathbf{x}$ & $x$ & $\mathbf{x}$ & \\
\hline U.A,E./Qatar & $\mathrm{X}$ & $\mathrm{X}$ & $\mathrm{x}$ & $\mathrm{x}$ \\
\hline Venezuela & $\mathrm{X}$ & $\mathrm{x}$ & & \\
\hline Other Afitica & & $\mathrm{X}$ & $\mathrm{x}$ & \\
\hline
\end{tabular}

Source: Energy Information Administration, International Energy Annual 1988, DOE/EIA-0219(88) (Washington, DC, November 1989), and International Energy Agency, data tape of Quarterly 011 Statist1cs, th1rd quarter 1989.

In a competitive oil market, a profit maximizing refiner would be coritinuously seeking that crude ofl mix which minimizes operating costs and maximizes profits. In general, the optimal crude ofl $\mathrm{mix}$ to a refinery changes as the avallable crude ofl and demand slate for refinery products change.

Charactertstics of Alaskan North Slope Crude 011

Alaskan North Slope (ANS) crude oll has an API gravity of $26.4^{\circ}$, and a sulfur content of 1.06 percent by welght. The assay of ANS crude Indicates that $1 t$ produces a very small fraction of gasoline range products (1sobutane, 11ght stralght-run gasoline, and light naphtha as gasoline blending components). The sum of these fractions is less than 8 percent (Tuble 4). In a market like the West Coast, which has very high gasoline demand, a great deal more 
Table 4. Alaskan North Slope Crude 011 Assay

Intermediate Products

Crude Fraction

Gas .......................................

Propane

0.002

Isobutane

0.005

N. Butane

$\ldots \ldots \ldots \ldots \ldots \ldots \ldots \ldots \ldots \ldots \ldots \ldots \ldots \ldots \ldots \ldots \ldots \ldots \ldots \ldots \ldots \ldots \ldots$

Light Straight Run, LON (C5-175)

Light Straight Run, ION (C5-175) $\ldots \ldots \ldots \ldots \ldots \ldots \ldots \ldots$

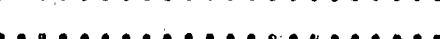

L1ght Stralght Run, HON (C5-175) $\ldots \ldots \ldots \ldots \ldots \ldots \ldots \ldots$

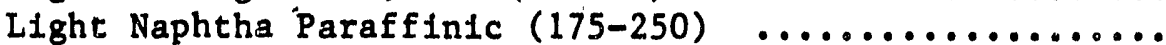

Light Naphtha Intermediate (175-250)

0.021

L1ght Naphtha Naphthenic (175-250)

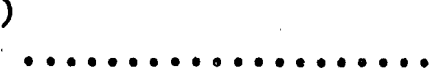

Naph $P(250-325)$

Naph I (250-325)

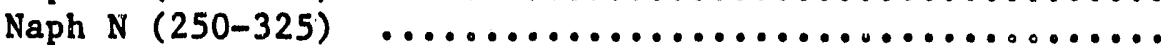

Heavy Naph $P(325-375) \quad \ldots \ldots \ldots \ldots \ldots \ldots \ldots \ldots \ldots \ldots \ldots$

Heavy Naph I $(325-375) \quad \ldots \ldots \ldots \ldots \ldots \ldots \ldots \ldots \ldots \ldots \ldots \ldots \ldots$

Heavy Naph N (325-375)

[.........................

Kero L. Flash P., LS/LM (375-500)

Kero H. Flash P., LS/LM (375-500)

Kero L. Flash P., HS/LM (375-500)

$\ldots \ldots \ldots \ldots \ldots \ldots \ldots \ldots \ldots$

$\ldots \ldots \ldots \ldots \ldots \ldots \ldots \ldots \ldots$

$\ldots \ldots \ldots \ldots \ldots \ldots \ldots \ldots$

Kero H. Flash P., LS/LM (375-500)

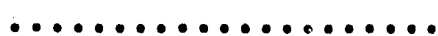

Dist111ate LS/LM (500-620)

Dist1llate MS/LM (500-620)

Distillate HS/LM (500-620)

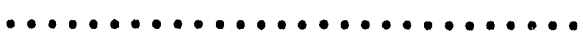

LIght Gas 011, N. LS (620-800)

Light Gas $011, N$. MS (620-800)

Light Gas $011, N$. HS $(620-800)$

Light Ga.s 011, P. LS (620-800)

Heavy Gas $011 \mathrm{~N}$, LS (800-BTMS)

Heavy Gas 011 N, MS (800-BTMS)

Heavy Gas $011 \mathrm{~N}$, HS (800-BTMS)

Heavy Gas 011 P, LS (800-BTMS)

Res1d. Low Sulfur (.2)

Res1d. H1gh Sulfur $(2.1)$

Resid. Very H1gh Sulfur (3.2)

Asphalt Very HIgh Sulfur (4.3)

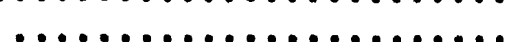

,$\ldots \ldots \ldots \ldots \ldots \ldots \ldots \ldots \ldots \ldots$

...................

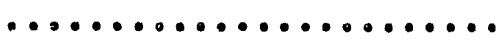

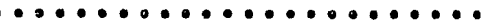

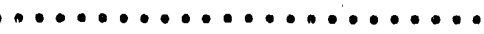

$\ldots \ldots \ldots \ldots \ldots \ldots \ldots \ldots \ldots \ldots \ldots$

$0.0 \div 3$

$\ldots \ldots \ldots \ldots \ldots \ldots \ldots \ldots \ldots \ldots$

0.030

$\ldots \ldots \ldots \ldots \ldots \ldots \ldots \ldots \ldots \ldots$

$\ldots \ldots \ldots \ldots \ldots \ldots \ldots \ldots \ldots \ldots$

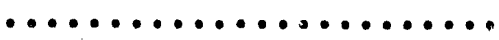

$\bullet \ldots \ldots \ldots \ldots \ldots ., \ldots, \ldots \ldots \ldots$

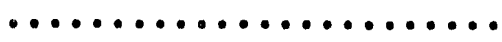

0.038

0.002

0.050

0.006

0.020

0.051

0.099

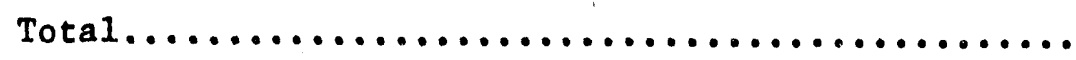

...................

0.057

0.072

0.045

0.130

0.155

1.000

Source: Energy Information Administration, Refinery Evaluation Modeling System (REMS) Model Documentation, DOE/EIA-0460 (Washingt 3 , DC, October 1984). 
processing is required to convert 11ght gas ofl, heavy gas o1l, and residual fuel to lighter products such as gasoline and fet fuel. The Fluld Catalytic Crackers and Hydrocrackers would be used to convert gas olls to gasoline and fet fuel, and the Coker process would be used to convert residual fuel to ilghter products. The additional processing adds to the cost of producing the lighter products on the West Coast.

In Japan, Southeast Asia, and Other Asla, the demand for distillate fuel and residual fuel is much greater than the demand for gasoline. Therefore, the processing required to convert a barrel of ANS crude to meet the demand siate In those areas would be much less than on the West Coast. In addition, the low sulfur content of ANS crude oll Implles a lower utilization of desulfurization units, which would further reduce the cost of processing ANS crude in these foreign regions relative to the West Coast.

\section{Transportation Costs}

In a competitive market environment, differences in the prices of Alaskan crude ofl in various reglonal markets cannot exceed differences in the costs of transporting the crude oll. Tanker rates, therefore, play a very important role in determining the movement of Alaskan crude ofl at the margin. In general, reglons which experience higher transportation costs must value the Alaskan ofl more highly, otherwise regions with lower transportation costs will simply recelve more oll unt1l the market for Alaskan oll reaches a new equilibrium.

Tanker rates for Alaskan ofl frow: Valdez to varlous potential forelgn refining reglons show that Japan has the lowest rate for both the large and very large crude carriers and that the rate to Singapore only slightly exceeds the rate to Los Angeles for large crude carrlers (Table 5 and Figure 5).

Would refinerles In Japan, Southeast Asla, and other Asian countries compete effectively with refinerles on the West Coast for at least some portion of Alaskan crude o11? The answer depends on the savings in processing costs that could be achleved by substituting Alaskan crude o1l for other Imported crudes as well as on the relative prices of Alaskan and internationally traded crudes and their transportation costs. The presumption is that Japanese refineries would be one of the strongest competitors for Alaskan crude, since the cost of transporting the crude to Japan 18 the lowest and the compatibility of that crude with the Japanese demand slate and refinery configuration is high. The TRIP model described in the next section that takes into account the interactions among all of these factors on a worldwide basis is used in order to reach a firm conclusion. 
Table 5. lanker Rates for Alaskan Crude 011 from Valdez to Varlous Ports by Type of Carrier in 1988 (Dollars per Barrel)

\begin{tabular}{lll}
\hline Destination & Large & vLCC \\
\hline New York & $3.079^{\mathrm{a}, \mathrm{b}}$ & $\mathrm{c}$ \\
Houston & $2.938^{\mathrm{a}, \mathrm{b}}$ & 4.147 \\
Los Angeles & $0.833^{\mathrm{a}}$ & $0.606^{\mathrm{a}}$ \\
Hovic, V1rgin Islands & $1.503^{\mathrm{b}}$ & 1.004 \\
Yokohama, Tipan & 0.552 & 0.315 \\
Sydney, Australia & 0.925 & 0.507 \\
Pulo Bukom, S1ngapore & 0.894 & 0.491 \\
Bombay, India & 1.210 & 0.663 \\
\hline
\end{tabular}

a Jones Act Tanker Rate.

Uses Panama Canal.

There are no VLCC port facilities in New York.

Note: VLCC - Very Large Crude Carrier.

Source: Platt's 011gram Price Report, October 31, 1988. 


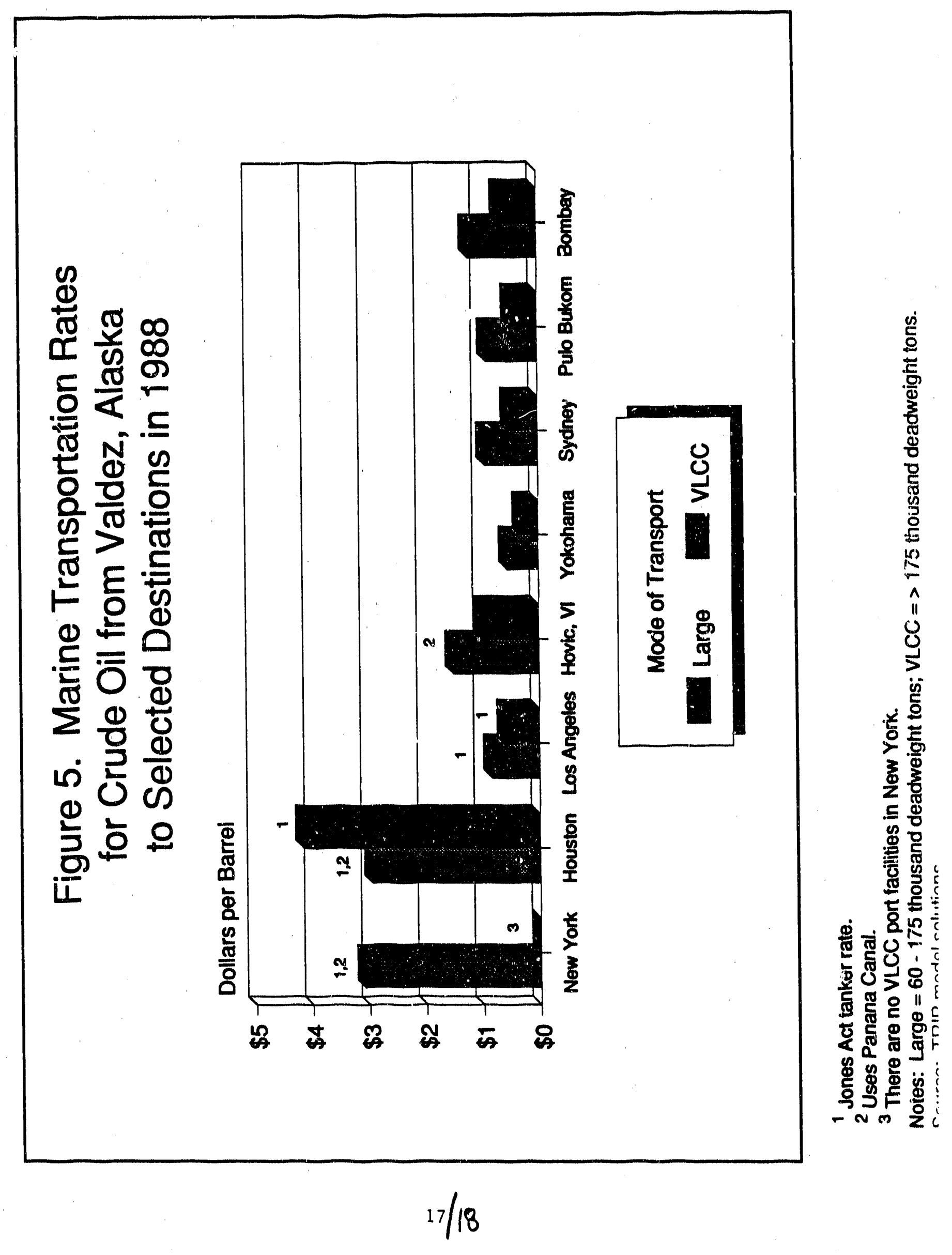




\section{METHODOLOGY}

The effects of lifting the ban on the export of Alaskan crude oll were investigated using the Energy Information Administration's (EIA's) Transportation and Refining of International Petroleum (TRIP) mode1. The TRIP model provides a simulation of worldwide petroleum activities including crude oll and natural gas liquids supply, petroleum product demand, marine transportation and pipeline distribution, and refinery opcrations. A linear programing formulation is used in order to satisfy fixed product demand slates while minimizing the sum of all global resource costs. There are no time dynamics in a TRIP model solution. A single solution represents an average daily operating plan for a specified time period (the calendar years 1988 and 1995 for this study).

Supply

A total of forty-nine worldwide crude oll streams are defined in the TRIP model. Thirteen of these crude ofls are domestically produced with the remalning thirty-six being Indigenous to foreign reglons. Each of these crude olls has a unique assay which reflects its processiug capabilities in the worldwide refining environment. Forty-elght of the crude oils are introduced to the TRIP model as production upper bounds. In the case of the 1988 simulations, these production upper bounds reflect the actual production levels achieved in 1988; the production levels in the 1995 simulations are EIA estimates. Saudi Arabian Light acts as the marginal wo:ld crude o1l supply. It is the only crude oil stream that is priced in the IRIP model, with a Free-On-Board (FOB) price of $\$ 14.15$ for 1988 and an estimated FOB price of $\$ 19.00$ (in constant 1988 dollars) for 1995. All other crude o1l streams are priced (marginal or "shadow" prices) relative to Saudi Arabian Light and reflect any quality or location differences.

In addition to crude ofl supplies, the TRIP model also considers three additional categorles of liquid raw materlals: natural gas liquids, other liquids (e. g., coal liquids and alcohol), and "unaccounted for" supply. It should be emphasized that all supply categories are introduced into the model as point estimates (with the exception of Saudi Arabian Light), 1.e., natural resource supplies for any given year are fixed. There are no iterative procedures in the TRIP model which use supply elasticities to vary production quantities as a function of marginal prices. 
Demands

The driving force behind a TRIP model simulation is the fixed slate of refined product demand quantities. Worldwide demands of refined products are disaggregated into ten categorles. These categorles include: premium unleaded gasoline (90-92 octane), regular unleaded gasoline (80-87 octane), gasoline with octane less than 80 , No. 2 Dist1llate Fuel 011, No. 4 Distillate Fuel 011, High Sulfur Residual Fuel 011, Low Sulfur Residual Fuel 011, Jet Fuel, Liquefied Petroleum Gases, and Other Petroleum Products (e.g., lubes, waxes, and still gas). In addition to refined product demands, demands for unrefined crude oll are specifled. Actual 1988 annual average demands were used for the 1988 TRIP model simulations; the 1995 simulations used EIA estimates. Whereas total worldwide petroleum demand 18 expected to -substantially Increase by 1995 , It is estimated that the relative shares across refined products will not appreclably change, with only a slight Increase in the shares of gasolines and middle distillates accompanied by a slight decrease in the shares of residual fuels and 11quefled petroleum gases. The marginal prices of refined products in the TRIP model are a function of crude ofl price, avallability, and quality; the cost of marine and pipeline movements; and the costs incurred in the refinery environment.

All refined product demands are introduced into the TRIP model as fixed point estimates that must be met. There are no iterative procedures which use demand elasticities to vary reglonal refined product consumption as a function of marginal prices.

Marine Transportation and PIneline Distribution

There are $81 x$ categorles of crude oll carriers in the TRIP model that differ by size, vessel operating characterlstics, and ownership. Ownersh1p refers to the distinction made between forelgn-flag vessels versus Jones Act tankers. Worldwide tanker routes are determined for each origin/destination port pair across all tanker categorles. These routes are a function of distance, ability to use canals, and ablifty to berth at a particular port. A marine transportation rate is assoclated with each tanker category/route combination and was derived for the TRIP model simulations using the 1988 Worldscale. Multiplier for foreign-flag vessels and the 1988 American Rate Multiplier for Jones Act tankers. Added to this derfved rate is the cost of bunker fuel, insurance, and part-cargo 11ghtering (where appropriate).

The elght categorles of refined product carriers in the TRIP model are represented in much the same way as the crude ofl carriers. There is a distinction made between vessels that transport clean versus dirty products. Assoclated with each tanker category (crude oll and refined product) is an upper bound that spectfies the total amount of deadwelght tonnage avallable at a particular point in time. Actual 1988 avallable deadweight tonnage was used for the 1988 TRIP model simulations; the 1995 simulations used a National Petroleum Council estimate of tanker avallability in 1990. Tanker 
availability was not a binding constraint in elther the 1988 or the 1995

simulations. One additional category of marine transportation considered in the TRIP model is river barge traffic.

Worldwide crude o1l, clean priuuct, and liquefled petroleum gas pipelines are represented in the TRIP model. The geographical coverage of the pipeline representations include: Inter-Petroleum Administration for Defense District (PADD) movements, movements across the Unfted States/Canadian border, Inter-country movement in Europe, Persian Gulf movements, the SUMED pipeline, and the Panama pipeline. Assoclated with each pipeline is a capacity and a cost. Actual 1988 capacities and costs were used for both the 1988 and 1995 TRIP model simulations.

\section{Worldwide Refining}

The TRIP model contains thirty-three Individual refinery models. The United States is represented by PADD-level formulations, while the rest of the world is represented by either national refinery models (e. g., West Germany and France) or higher levels of aggregation. There are no refinery formulations for the Centrally Planned Economies. A given regional refinery representacton is defined as the sum of capacities across all individual processing units within that geographical region. Admittedly, this level of aggregation might tend tc overstate a region's refining capability; however, model validation efforts in the past have not shown significant discrepancles when comparing model results with a region's historical refinery output.

Lending additional credibility to this particular set of worldwide refinery models is the fact that they were used extensively in the National Petroleum Council (NPC) study on U.S. Petroleum Refining (October 1986). The NPC, employing a group of industry experts on regional refinery operations, examined with great care the assumptions, methodology, and results of the EIA's refinery modeling capabilities. Having been subjected to this rigorous validation process, the current worldwide refining formulations in the TRIP model re regarded as credtble representastons of worldwide refining operations.

Twenty-four different types of refinery processes are represented in the TRIP model ranging from straight distillation to the more sophisticated downstream processes found in the more complex (therefore, more flexible) refining environments such as the Unfted States, certain European countries, and Japan. Assoclated with each refinery process is a capacity upper bound and a cost. The cost includes processing and blending operations as well as the return on Investment (capital recovery). Both the 1988 and 1995 TRIP model simulations used 1988 process unft capacity upper bounds and refining costs. 
An interesting feature of the TRIP model is 1ts abllity to stlpulate fust how close a given solution should adhere to historlc patterns of crude ofl and refined product trade. Th1s is done on a percentage basis by declaring that a given exporter of crude oll or refined products must not deviate from its historic export shares by more than a certain percentage. Th1s feature was included in the TRIP model formulation because it was recognized that the stralght economics of transportation and refining could not adequately capture the institutional constraints (long-term contracts, diversification of supply sources, trade restraints, etc.) of the world petroleum market.

A 1988 and a 1995 business-as-usual (BAU) simulation were generated for this exercise. Because 1988 refinery runs are known, the 1988 BAU simulation allowed virtually no deviation from actual 1988 crude o1l trade patterns. Therefore, the crude o1l refinery runs in the United States and the Far East: were for all purposes Identical to the actual 1988 refinery runs. Reflned product trade patterns were not locked in because the locking in of crude runs implicitly determines the avallability of refined products for export. Because there is a good deal of uncertainty associated with petroleum trade in 1995, trade shares for both crude o11 and refined products were allowed to deviate by up to 20 percent from their 1988 historfc shares in the 1995 BAU simulation.

Sensitivity simulations were generated for both 1988 and 1995 . The ban on exporting Alaskan crude oll was lifted in 200 thousand barrel per day increments across the sensitivity cases with the final sensitivity case being a totally unrestricted Alaskan export case. In the sensitivity cases, regional refinery runs were upper bounded at their BAU levels. United States refiners were allowed to only give up their runs of Alaskan crude oil but could increase thelr runs of any other domest1c or forelgn crude oll. Far Eastern refiners were allowed to import Alaskan crude o1l but could only decrease the1r runs of any other domestic or 1mported crude o11. Refined product trade was allowed to devlate by up to 20 percent of 1 ts BAU import and export levels. There were no restrictions placed on the composition of the refined product Imports and exports. 


\section{ANALYSIS OF RESULTS}

Crude ofl and petroleum product markets would both be affected if the ANS crude ofl export ban were eliminated. The later the year of its elimination, the smaller the effects. The reason is that production of Als crude o1l will likely continue to decline sharply in the near future and its price will likely rise toward free-market levels even with the ban in effect. Product prices on the West Coast will not be greatly affected since they are effectively constrained by unrestricted product trade in international markets and by the reduction in West Coast processing costs resulting from the increased use of imported crudes that are better sulted to produce gasoline.

\section{Implications for Crude 011 Prices and Trade}

Substantial volumes of Alaskan North Slope (ANS) crude ofl would probably be exported and its price would rise if the Alaskan oll export ban were eliminated. The relativily higher value that Paciflc RIm refinerles place on ANS crude relative to the price of that crude on the West Coast with the ban in effect is the reason for this conclusion. However, the magnttudes of the likely export volumes and price increases depend on the year in which the ban is assumed to be eliminated, since the production of ANs crude is declining rapidly. If the ban had been eliminated in 1988, the effects could have been large. If the ban were eliminated in 1995, export volumes would be substantially smaller and price effects would probably be negligible.

Up to 1.5 million barrels per day, or three-fourths, of Alaska's crude ofl production could have been exported in 1988 if the ban had been eliminated in that year, and 1ts price (refinery acquisition cost) on the West Coast could have Increased by over $\$ 2.00$ per barrel. If, on the other hand, the ban were eliminated in 1995, only 400 thousand barrels per day of a sharply lower level of production would likely be exported in that year and the price would increase by only about $\$ 0.20$ per barrel (In constant 1998 dollars). These Increases assume instantaneous adfustment of all markets to the new equilibrium levels. In practice, some time would be required before markets adfust completely. The smaller, market-constrained increases are equivalent to those that would result from a partial lifting of the export ban rather than its complete elimination.

\footnotetext{
${ }^{3}$ All prices in this report are in constant (1988) dollars.
} 
Figures 6 and 7 depict the relationship between the volumes of ANS crude o11 shipped to West Coast refineries and the refinery acquisition cost of that crude at varfous constrained and unconstrained levels of ANS exports. The greater the volume of exports, the higher the price. In 1988, for example, the price of ANS crude could have risen by nearly $\$ 1.00$ per barrel if allowable exports had been constralned to 800 thousand barrels, and by over $\$ 2.00$ per barrel if the export ban had been fully eliminated.

Generally, the volumes of ANS crude shipped to the West Coast decline as the export ban is increasingly relaxed (Table 6). However, at low export levels, shlpments to the West Coast would likely have remalned essentlally unchanged in 1988 since the volumes exported would have been obtained by curtalling shipments to other U.S. markets (Table 7). Shipping ANS crude to those markets is expensive. In 1995, however, there would not likely be any ANS crude shipments to other U.S. markets, because of the lower level of ANS crude production. All exports in that year would therefore result from diverting shipments away from the West Coast. However, exports would not likely exceed 400 thousand barrels per day (and prices would not likely increase by more than $\$ 0.20$ per barrel) alnce forelgn crudes would be more economical for forelgn refiners at the higher prices required to induce additional ANS exports.

Table 6. West Coast Price-Quant1ty Relationships for ANS Crude 011 at Var1ous Export Leve1s, 1988 and 1995

\begin{tabular}{|c|c|c|c|}
\hline $\begin{array}{c}\text { Maximum } \\
\text { Allowable } \\
\text { ANS Exports } \\
\text { (MB/d) }\end{array}$ & $\begin{array}{c}\text { ANS } \\
\text { Shipments to } \\
\text { West Coast } \\
\text { (MB/d) } \\
\end{array}$ & $\begin{array}{r}\text { Ref } \\
\mathrm{C} \\
\text { Constant } \\
\end{array}$ & $\begin{array}{l}\text { Inery Acquis1 } \\
\text { ost of ANS Cr } \\
\text { on West Coas } \\
1988 \text { Dollars }\end{array}$ \\
\hline & \multicolumn{3}{|c|}{1988} \\
\hline $\begin{array}{r}0 \\
200 \\
400 \\
600 \\
800 \\
1,000 \\
1,200 \\
1,400 \\
\text { Unbounded }\end{array}$ & $\begin{array}{r}1,381 \\
1,381 \\
1,381 \\
1,291 \\
1,191 \\
991 \\
791 \\
591 \\
466\end{array}$ & , & $\begin{array}{r}\$ 13.49 \\
13.64 \\
13.74 \\
13.99 \\
14.43 \\
14.82 \\
15.25 \\
15.46 \\
15.65\end{array}$ \\
\hline
\end{tabular}

$\underline{1995}$

$\begin{array}{crr}0 & 1,255 & 20.98 \\ 200 & 1,055 & 21.11 \\ 400 & 855 & 21.17 \\ \text { Unbounded } & 849 & 21.17\end{array}$

MB/d - Thousand barrels per day.

Source: TRIP model solutions. 


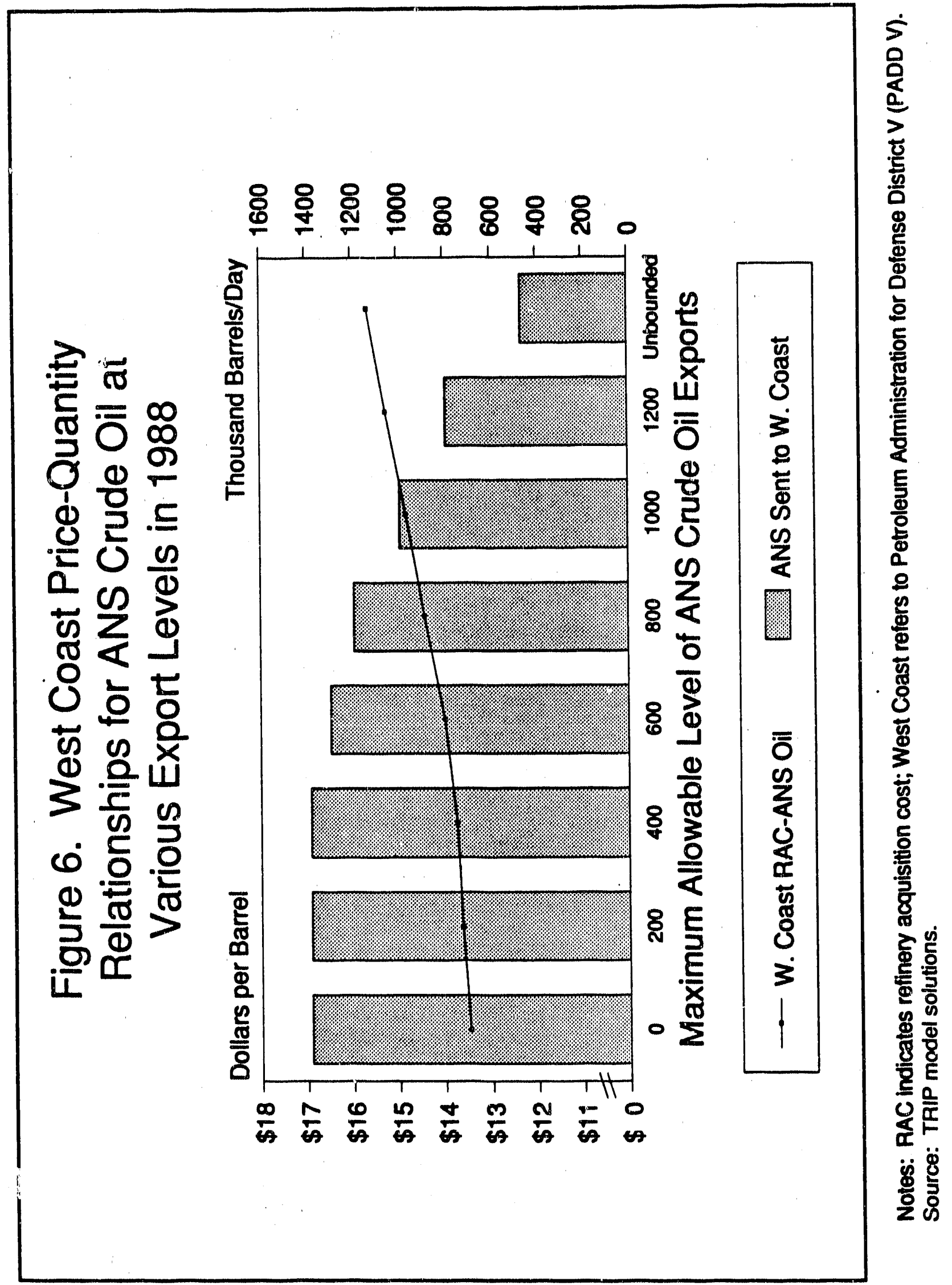




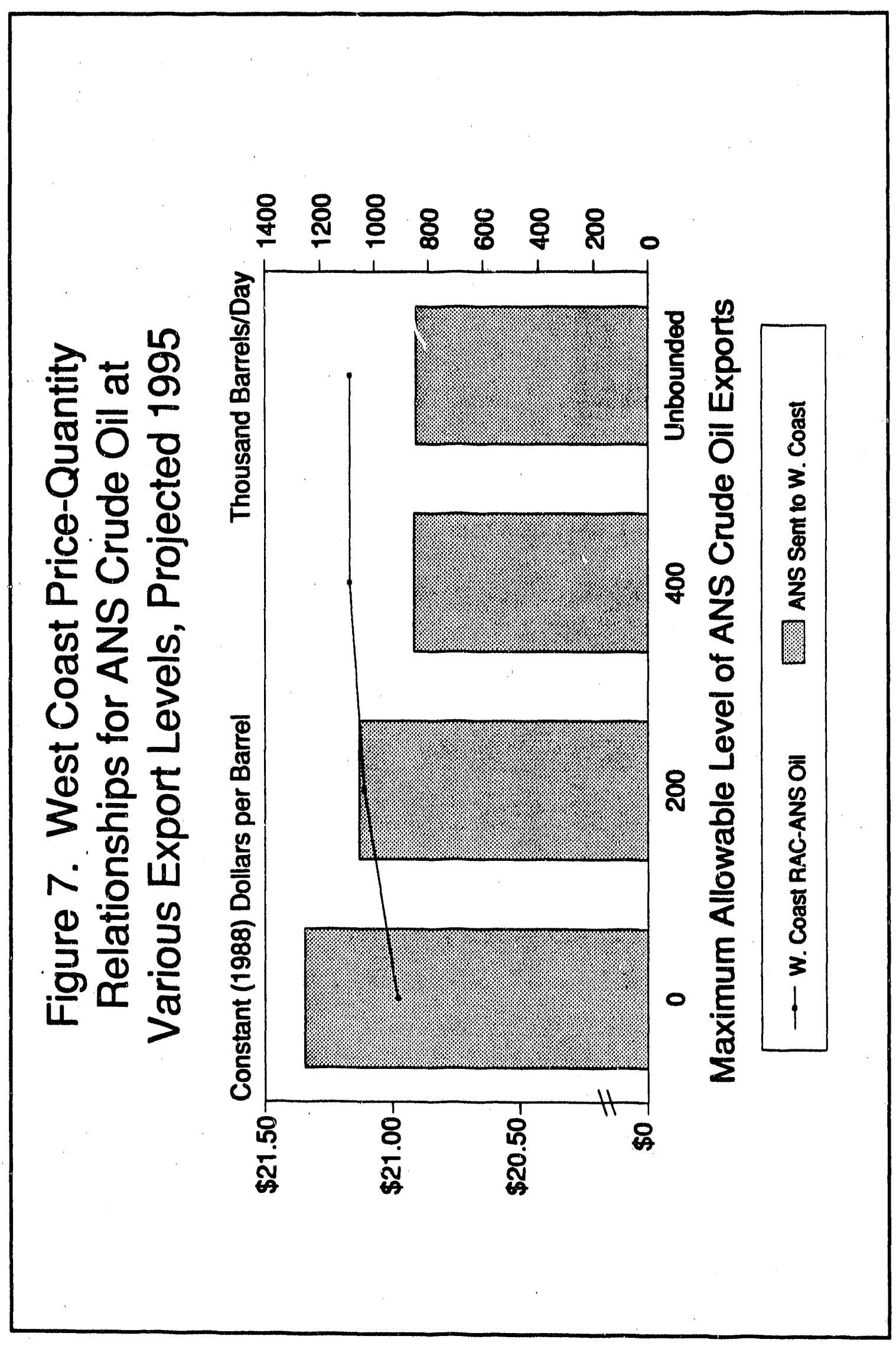

ड) 
Table 7. Changes in ANS Crude 011 Shlpments to Domestic Outlets in 1988 and 1995 Resulting from Constrained and Unconstrained Exports of ANS Crude 011 (Thousand Barrels per Day)

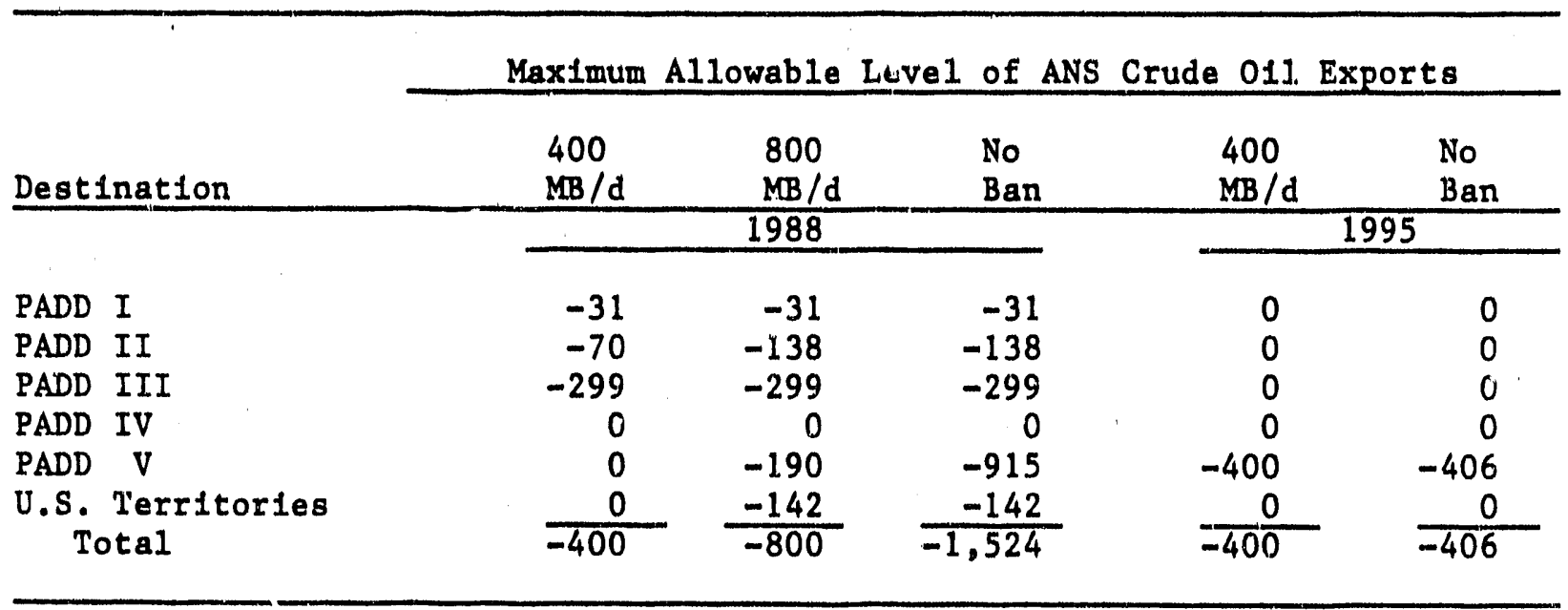

Notes: o P $: D D$ means Petroleum Administration for Defense District. PADD V 1s the We'st Coast, which conslsts of Alaska, Arizona, California, Hawa11, Nevada, Uregon and Washington. O Sum of components may not equal total due to indeyendent rounding.

Source: TRIP midel solutions.

The refinery acquisition costs of all other crudes produced on the West Coast, not fust ANS crude, could also increase if the Alaskan ban were eliminated. The increases for these other crudes may roughly approximate those for ANS crude at various export levels for both 1988 and 1995 (Table 8).

It is estimated that exports of ANS crude ofl could be directed entirely to Japan and other Asian markets if the ban were lifted (Table 9). Alaskan North Slope crude is better sulted to the production of middle distillates, for which there is a relatively greater demand in those markets than on the West Coast. The Asian preference for ANS crude is reflected in the higher valuation placed on that crude relative to 1 ts value on the Nest Coast and relative to the value of other crudes with the ban in effect. In 1988, for. example, 1t is estimated that Japan valued ANS crude delivered to 1 ts refinerles by about $\$ 2.00$ per barrel more than the value of that crude on the West Coast and by about $\$ 0.60$ per barrel more than for crudes imported from other sources. If the ban had been eliminated in that year, 60 percent of the maximum 1.5 million barrels per day of exported ANS crude could have been shipped to Japan. At a constrained ANS export level of 800 thousand barrels per day, 500 thousand barrels per day could have been sent there. At a constralned export level of 400 thousand barrels per day, about 220 thousand barrels per day could have been directed to that country. If the ban were eliminated in 1995 Instead of 1988, three-fourths of the totally unconstrained export level of 400 thousand barrels per day in that year might be shipped to Japan. 
Table 8. Increases in West Coast Refinery Acquisition Costs of Cruce 011 Produced in that Area at Varlous Export Leve1s, 1988 and 1995 (Constant 1988 Dollars per Barrel)

Maximum Allowable Level of ANS Crude 011 Exports

Crude Source

$400 \mathrm{MB} / \mathrm{d}$

$800 \mathrm{MB} / \mathrm{d}$

Unbounded

1988

Alaskan North Slope

All Other West Coast Total West Coast

\begin{tabular}{|c|c|c|}
\hline $\begin{array}{r}\$ 0.25 \\
.24 \\
.25\end{array}$ & $\begin{array}{r}\$ 0.94 \\
\quad .88 \\
.89\end{array}$ & $\begin{array}{r}\$ 2.16 \\
2.00 \\
1.85\end{array}$ \\
\hline & 1995 & \\
\hline $\begin{array}{l}0.19 \\
0.21 \\
0.08\end{array}$ & $\begin{array}{l}\text { NA } \\
\text { NA } \\
\text { NA }\end{array}$ & $\begin{array}{l}0.19 \\
0.21 \\
0.08\end{array}$ \\
\hline
\end{tabular}

Alaskan North Slope

All Other West Coast

Total West Coast

0.21

NA

0.21

NA = Not applicable.

Note: The Increase in the cost for Total West Coast crude is usually less than the increases in the costs of Individual West Coast crudes because of changes in the relative volumes of the different types of crude. Specifically, the Increase in the cost for l'otal West Coast crude is the difference in the weighted averages of the Individual cost levels rather than the weighted average of differences in those levels. The welghts are the volumes of Individual crudes produced on the West Coast that were acquired by refinerles in the region. The volumes change according to the maximum allowable level of ANS crude oll exports.

Source: TRIP model solutions.

The 1088 of ANS crude to U.S. refiners through exports would 11kely be compensated for by an essentially equal increase in the volume of Imported crude (Table 9). If the ban had been eliminated In 1988, most of the Increase would likely have orlginated from Latin America (particularly Mexico and Fcuador), the M1ddle East (especlally the Unfted Arab Emirates and Qatar), and Malaysla. If the ban were eliminated in 1995, nearly all of the Increase would likely come from the United Arab Emirates and Qatar. Latin American crudes are generally heavier than Middle East crudes and not as well sulted to meet U.S. demand for light products. Middle East crudes can more readily accommodate the 1995 increase in U.S. Import demand since that Increase is only one-fourth as great as the 1988 increase. The increase in imports would have gone to the Gulf and West Coasts and to U.S. territorles in 1988 but would 11kely go only to the West Coast in 1995, since ANS shipinents to beyond the West Coast would have been fully backed out prior to 1995 . 
Table 9.' Changes in U.S. Crude 011 Exports ard Imports in 1988 and 1995 Resulting from Constralned and Unconstralned Exports of ANS Crude 011

(Thousand Barrels per Day)

\begin{tabular}{|c|c|c|c|c|c|}
\hline \multirow[b]{2}{*}{$\begin{array}{l}\text { Destination/ } \\
\text { Source }\end{array}$} & \multicolumn{5}{|c|}{ Maximum Allowable Level of ANS Crude 0.11 Exports } \\
\hline & $\begin{array}{l}400 \\
M B / d\end{array}$ & $\begin{array}{l}800 \\
\text { MR / d }\end{array}$ & $\begin{array}{l}\text { No } \\
\text { Ban }\end{array}$ & $\begin{array}{l}400 \\
\mathrm{MB} / \mathrm{d}\end{array}$ & $\begin{array}{l}\text { No } \\
\text { Ban }\end{array}$ \\
\hline & \multicolumn{3}{|c|}{1988} & \multicolumn{2}{|c|}{1995} \\
\hline & \multicolumn{5}{|c|}{ A. Exports } \\
\hline $\begin{array}{l}\text { Japan } \\
\text { Australia/N.Z. } \\
\text { Southeast Asla } \\
\text { Other Asla } \\
\text { Other Fore1gn } \\
\text { Total }\end{array}$ & $\begin{array}{r}220 \\
0 \\
0 \\
180 \\
0 \\
400\end{array}$ & $\begin{array}{r}501 \\
0 \\
0 \\
299 \\
0 \\
800\end{array}$ & $\begin{array}{r}886 \\
0 \\
0 \\
639 \\
0 \\
1,525\end{array}$ & $\begin{array}{r}309 \\
0 \\
0 \\
91 \\
0 \\
400\end{array}$ & $\begin{array}{r}315 \\
0 \\
0 \\
91 \\
0 \\
406\end{array}$ \\
\hline $\begin{array}{c}\text { Other Forelgn } \\
\text { Total }\end{array}$ & \multicolumn{5}{|c|}{ B. Imports } \\
\hline $\begin{array}{l}\text { Ecuador } \\
\text { Mexico } \\
\text { Trinidad } \\
\text { Bollvia/Peru } \\
\text { Kuwa1t } \\
\text { UAE/Qatar } \\
\text { Iraq } \\
\text { Malaysia } \\
\text { All Other } \\
\quad \text { Total }\end{array}$ & $\begin{array}{r}0 \\
337 \\
0 \\
63 \\
0 \\
0 \\
0 \\
0 \\
0 \\
400\end{array}$ & $\begin{array}{r}148 \\
461 \\
38 \\
111 \\
0 \\
42 \\
0 \\
0 \\
0 \\
800\end{array}$ & $\begin{array}{r}162 \\
377 \\
68 \\
149 \\
0 \\
502 \\
0 \\
238 \\
29 \\
1,525\end{array}$ & $\begin{array}{r}0 \\
0 \\
0 \\
0 \\
-101 \\
515 \\
-138 \\
99 \\
23 \\
398\end{array}$ & $\begin{array}{r}0 \\
0 \\
0 \\
0 \\
-101 \\
519 \\
-143 \\
98 \\
32 \\
405\end{array}$ \\
\hline
\end{tabular}

Source: TRIP model solutions. 
The welghted average West Coast refinery acquisition cost of Imported and domestlcally-produced crudes could Increase if the export ban were eliminated. The 1988 Increase could have amounted to nearly $\$ 0.25$ per barrel at the 400 thousand barrel per day ANS export level, less than $\$ 1.00$ per barrel at the 800 thousand barrel per day level, and nearly $\$ 2.00$ per barrel at the unconstrained export level (Table 10). It is estimated that prices would not Increase substantialily in 1995, regardless of the level of exports. Nearly all of the Increases in elther year originate from Increases in the price of domestically-produced crude. The only exception is at the unconstrained level of exports in 1988, where the refinery acquisition cost of 1mported crude Increased by $\$ 0.55$ per barrel while that for domestic crude Increased by nearly $\$ 2.00$ per barrel.

Table 10. Changes in West Coast Refinery Acquisition Cost of Crude 011 from Domestic and Fore1gn Sources, by ANS Export Leve1, 1988 and 1995 (Constant 1988 dollars per Barre1)

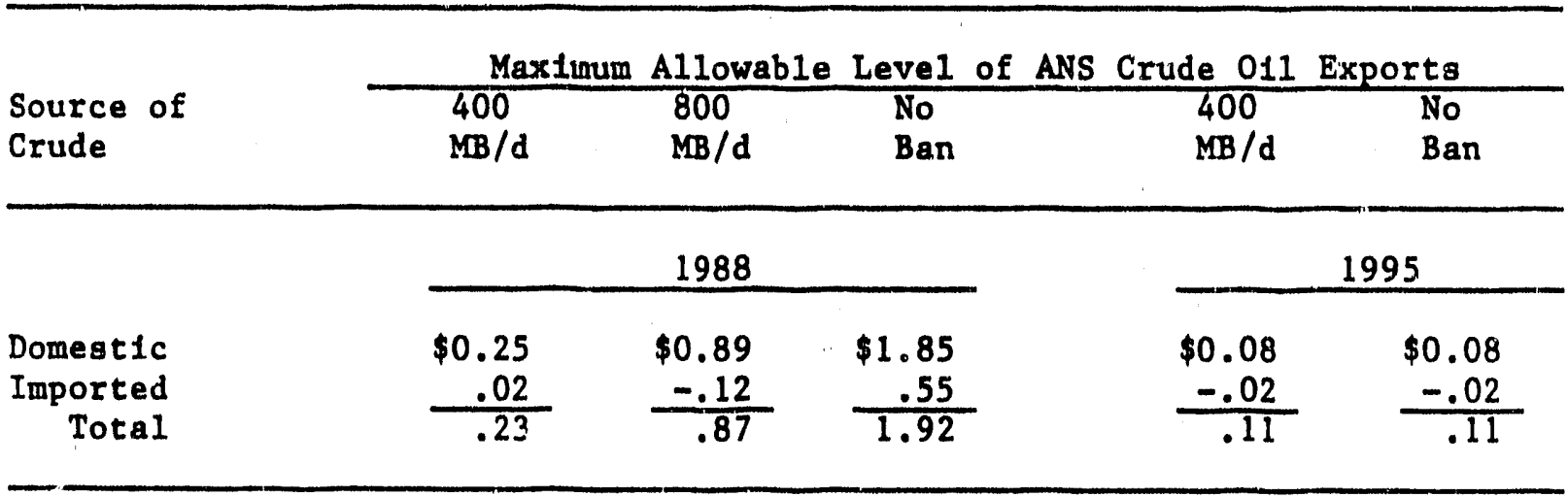

Note: The Increase in the cost of all crude acquired by West Coast refineries usually exceeds the change in the costs of elther of the two component crudes because of changes in the relative volumes of those crudes. Specifically, the increase in the cost of all crude is the difference in the welghted averages of the individual cost levels rather than the weighted average differences in those levels. The welghts are the volumes of Individual crudes acquired by refineries on the West Coast and the volumes change according to the maximum allowable level of ANS crude o1l exports.

Source: TRIP model solutions.

\section{Implications for Petroleum Products}

World demand for refined petroleum products is expected to continue to grow over the 1988 to 1995 period. Growth will I1kely be faster in the Pactfic Basin countries than on the U.S. West Coast. Total petroleum demand could grow by over 15 percent in Australla/New Zealand and by over 20 percent in the 
other Paciflc Basin countries, with only about 5 percent on the West Coast. This would result in an increased consumption of refined products of almost 2 million barrels per day In the Paclfic Basin versus an Increase of only about 100 thousand barrels per day on the West Coast. Although total product demand will Increase, the market share for individual products, Including gasoline, is expected to remain about the same within each of the two regions.

Gasoline market shares are expected to continue to remaln small in the Pacific Basin and large on the West Coast over the 1988 to 1995 perfod. The small changes in gasoline's markat share that do occur are not expected to alter the competitiveness of ANS crude 011, which produces only a very small fraction of gasollne-range products. For example, wh1le dafly Japanese demand for gasoline is expected to grow by 200 thousand barrels from 1988 to 1995 , dally total product demand in that country should grow by about one million barrels, leaving gasoline market shares essentially unchanged.

The elimination of the ANS crude oll export ban is not likely to greatly affect West Coast petroleun product markets in terms of prices, aggregate refinery output, or trade. Increases in product prices would be constralned by the use of a revised cride slate that would reduce processing costs and largely offset the Increase in refinery acquistition costs. Aggregate refinery output is not expected to change substantlally in the year in which the ban is eliminated but the composit:Ion of the output would 11kely shift to 11ghter products consistent with the product demand slate on the West Coast.

International product trade Involving the West Coast is expected to decline as Import requirements for light products and exports of heavier products both decrease. The effects in 1.988 on West Coast product markets resulting from the elimination of the ban In that year would be greater than if the ban were eliminated in 1995 since Wist Coast markets would be closer to free-trade conditions in the latter year.

On average, the welghted arerage Increase in product prices is estimated to be about 1 cent per gallon in 1988 if the ban had been fully eliminated in that year and would decrease by a smaller amount if the ban were eliminated in 1995. The different direction of product price change in the 2 years bastcally results from differences in the magnitudes of crude ofl price Increases.

${ }^{4}$ The East-West Center, a national educational center which focuses on energy markets in the Paclfic RIm, also projects that product market shares for the West Coast, Japan, and the Asla-Pacific reglons will be relatively unchanged to 1995. Those profections are consistent with MITI's 1989-1994 projections for Japanese fuel shares. See East-West Center Petroleum Adv1sory No. 43: World 011 Supply and Demand Outlook to 2000 (Honolulu, Hawall, October 1989) and Japanes( Ministry of International Trade and Industry (MITI), 5-Year Petroleum Supply P) an (Japan, Apr11 1990). 
Gasoline accounts for the bulk of refinery output on the Wast Coast and residual fuel ofl for most of the remalnder. If the ban had been eliminated In 1988, the refinery gate price of gasoline in that region could have Increased by about $\$ 0.50$ per barrel (or slightly more thai 1 cent per gallon) In that year and the price of residual by silghtly less (Table 11). The estimated smaller rise in residual fuel oll prices than in gasoline prices reflects the fact that West Coast refinerles would produce resldual fuel froin less expensive crude streams such as Arab L1ght, while gasoline would be produced from more expenstve streams. Although the results are somewhat different for 1995, the price changes Involved are quite small, reflecting the fact that ANS crude prices would quite 11kely have already risen close to free-market levels in that year even with the han in effect and that the elimination of the ban would have iftele effect on refinery a/squisition costs and product prices.

Table 11. West Coast Refinery Gate Product Prices at Varilous ANS Export Levels, 1988 and 1995

\begin{tabular}{|c|c|c|c|c|}
\hline \multirow{2}{*}{$\begin{array}{l}\text { Maximum } \\
\text { Allowable } \\
\text { ANS Crude } \\
\text { O11 Exports } \\
\text { (MB/d) } \\
\end{array}$} & \multicolumn{4}{|c|}{$\begin{array}{l}\text { Product Prices } \\
\text { (Constant } 1988 \text { Dollars per Barre1) } \\
\end{array}$} \\
\hline & $\begin{array}{l}\text { Premium } \\
\text { Gasoline }\end{array}$ & $\begin{array}{l}87 \text { Octane } \\
\text { Unleaded }\end{array}$ & $\begin{array}{l}\text { High-Sulfur } \\
\text { Residual }\end{array}$ & $\begin{array}{l}\text { Low-Sulfur } \\
\text { Restdual }\end{array}$ \\
\hline \multirow[b]{2}{*}{$\begin{array}{l}\text { Base } \\
200 \\
400 \\
600 \\
800 \\
1,000 \\
1,200 \\
1,400 \\
\text { Unbounded }\end{array}$} & \multicolumn{3}{|c|}{1988} & \multirow[b]{2}{*}{$\begin{array}{r}\$ 15.03 \\
15.03 \\
14.97 \\
14.99 \\
14.97 \\
15.09 \\
15.26 \\
15.36 \\
15.41\end{array}$} \\
\hline & $\begin{array}{r}\$ 22.26 \\
22.22 \\
22.21 \\
22.22 \\
22.38 \\
22.65 \\
22.79 \\
22.80 \\
22.80\end{array}$ & $\begin{array}{r}\$ 20.80 \\
20.77 \\
20.76 \\
20.80 \\
20.92 \\
21.08 \\
21.21 \\
21.27 \\
21.28\end{array}$ & $\begin{array}{r}\$ 14.74 \\
14.74 \\
14.72 \\
14.76 \\
14.78 \\
14.88 \\
15.06 \\
15.17 \\
15.23\end{array}$ & \\
\hline \multicolumn{5}{|c|}{1995} \\
\hline $\begin{array}{c}\text { Base } \\
200 \\
400 \\
\text { Unbounded }\end{array}$ & $\begin{array}{l}28.83 \\
28.62 \\
28.47 \\
28.47\end{array}$ & $\begin{array}{l}27.28 \\
27.23 \\
27.13 \\
27.13\end{array}$ & $\begin{array}{l}20.36 \\
20.47 \\
20.31 \\
20.31\end{array}$ & $\begin{array}{l}20.65 \\
20.74 \\
20.74 \\
20.74\end{array}$ \\
\hline
\end{tabular}

Surce: TRIP model solutions. 
The use of crudes in West Coast refineries that are better suited to meet final product demands in that area affects product trade. West Coast product imports could have declined by 55 thousand barrels per day to 130 thousand barrels per day in 1988 if the ban had been eliminated in that year, depending on whether ANS crude o1l exports are assumed to have been at the 800 thousand barrel per day level or at the unrestricted level of 1.5 million barrels per day, respectively (Table 12 and Figure 8). Most of the curtallment in product imports at the unrestricted crude oll export level is $11 k e l y$ to have been in unleaded gasoline, reflecting the Increased West Coast production of that product. Product imports would decline by a smaller volume in 1995, about 65 thousand barrels per day at the unrestricled ANS export level (Table 12 and Figure 9). The entire reduction would be in unleaded gasoline.

Table 12. Changes in Petroleum Product Imports Into the West Coast at Various ANS Crude 011 Export Levels, by Type of Product, 1988 and 1995 (Thousand Barrels per Day)

\begin{tabular}{|c|c|c|c|c|}
\hline \multirow{2}{*}{$\begin{array}{l}\text { Maximum } \\
\text { Allowable } \\
\text { ANS Crude } \\
\text { O11 Exports } \\
\text { (MB/d) }\end{array}$} & \multicolumn{4}{|c|}{ Product } \\
\hline & $\begin{array}{l}\text { Unleaded } \\
\text { Gasoline }\end{array}$ & $\begin{array}{l}\text { Jet } \\
\text { Fuel } \\
\end{array}$ & $\begin{array}{c}\text { A11 } \\
\text { Other }\end{array}$ & Total \\
\hline \multirow{3}{*}{$\begin{array}{c}200 \\
400 \\
600 \\
800 \\
1,000 \\
1,200 \\
1,400 \\
\text { Unbounded }\end{array}$} & \multicolumn{3}{|c|}{1988} & \\
\hline & $\begin{array}{r}2 \\
1 \\
-9 \\
-15 \\
-41 \\
-70 \\
-92 \\
-106\end{array}$ & $\begin{array}{r}1 \\
-9 \\
-31 \\
-34 \\
-11 \\
-5 \\
-12 \\
-16\end{array}$ & $\begin{array}{r}-7 \\
0 \\
-7 \\
-7 \\
-7 \\
-7 \\
-7 \\
-7\end{array}$ & $\begin{array}{r}-5 \\
-8 \\
-46 \\
-55 \\
-58 \\
-82 \\
-110 \\
-129\end{array}$ \\
\hline & & 199 & & \\
\hline $\begin{array}{c}200 \\
400 \\
\text { Unbounded }\end{array}$ & $\begin{array}{l}-30 \\
-66 \\
-66\end{array}$ & $\begin{array}{l}0 \\
0 \\
0\end{array}$ & $\begin{array}{l}0 \\
0 \\
0\end{array}$ & $\begin{array}{l}-30 \\
-66 \\
-66\end{array}$ \\
\hline
\end{tabular}

Notes: O Sum of components may not equal total due to independent rounding. O May include changes in shipments into the West Coast from other PAD districts.

Source: TRIP model soluticns. 


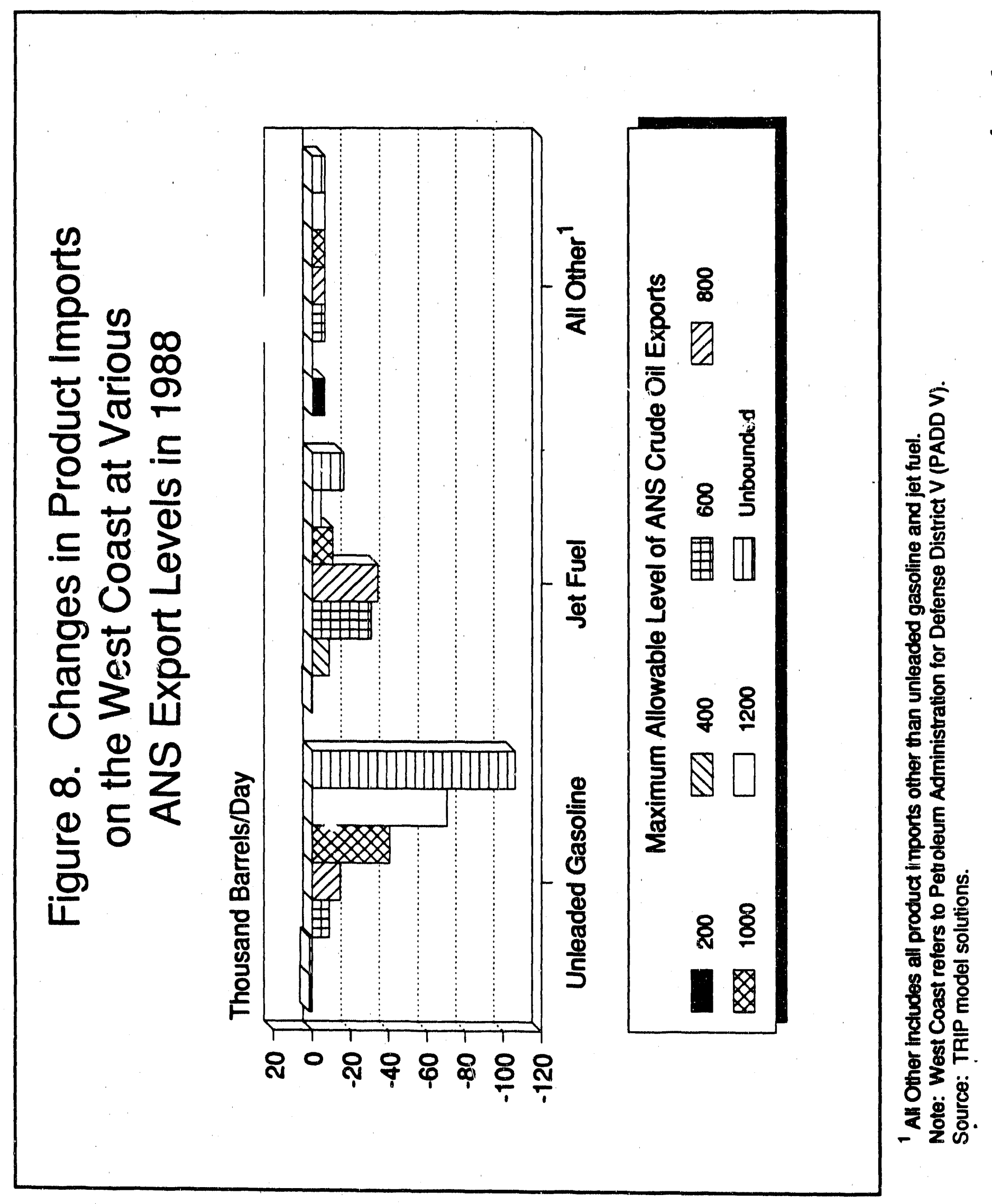




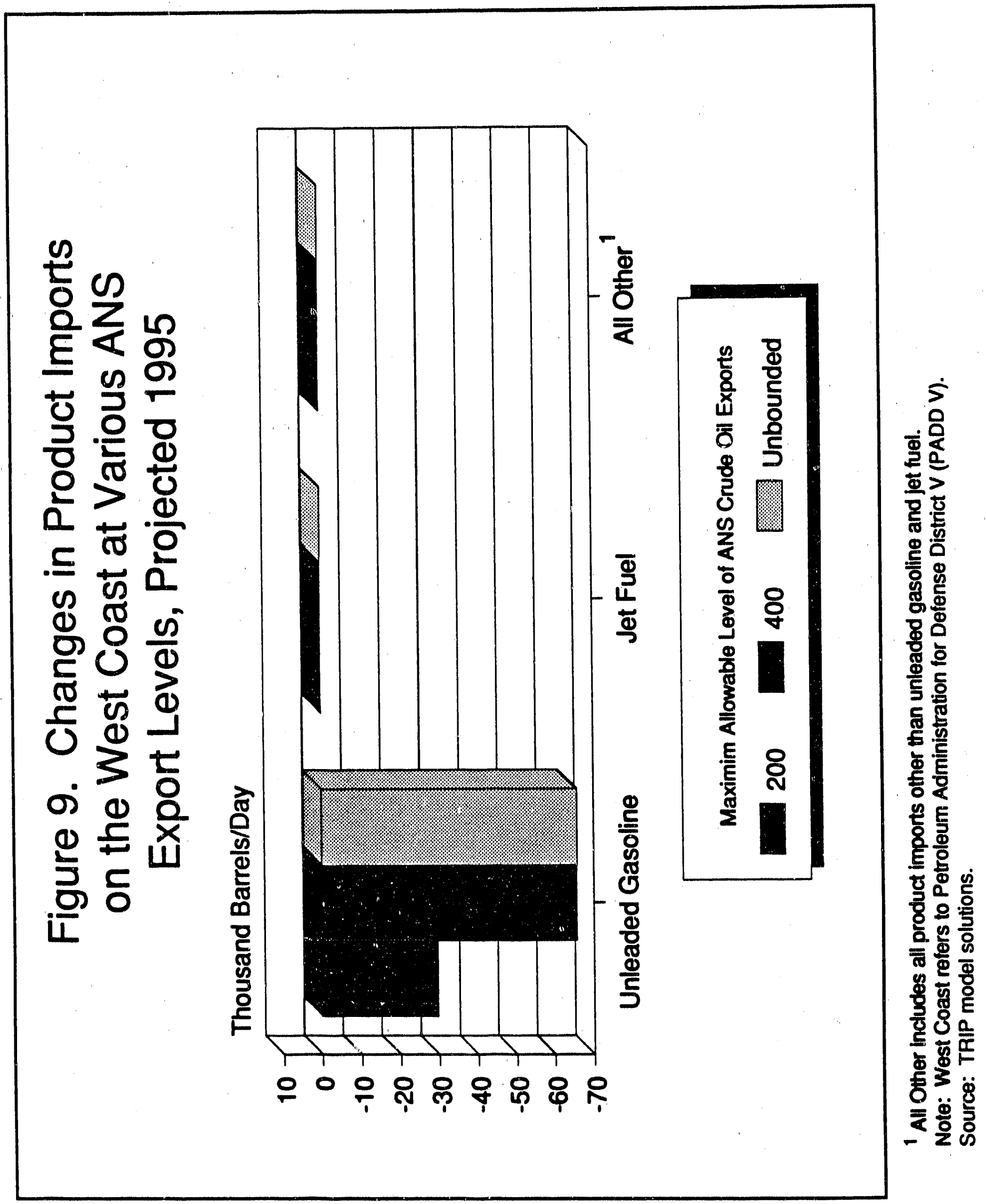


West Coast total product exports are estimated to decline in amounts roughly equal to the decline in product imports. The decrease in 1988 would 11kely have been principally in low sulfur residual, the production of which would have declined as more gasoline was produced in West Coast refineries. The amount of cutback in the export of that product is directly related to the volume of ANS exports. The cutback could have reached 130 thousand barrels per day (at the unrestricted ANS crude ofl export leve1) in 1988 (Table 13 and Figure 10). The cutback in product exports in 1995 would 11kely be substantlally smaller and would likely be almost entirely in No. 2 distillate oll (Table 13 and Figure 11).

Table 13. Changes in Petroleum Product Exports from the West Coast at Varlous ANS Crude 011 Export Levels, by Type of Product, 1988 and 1995 (Thousand Barrels per Day)

\section{Maximum Allowable ANS Crude 011 Exports $(\mathrm{MB} / \mathrm{d})$}

\section{Product}

\begin{tabular}{lccc}
\hline $\begin{array}{c}\text { Low-Sulfux } \\
\text { Residual }\end{array}$ & No. 2 & Al1 & \\
Distillate & Other & Total \\
\hline
\end{tabular}

\section{8}

$\begin{array}{lrlrr}200 & 2 & 0 & -7 & -5 \\ 400 & -7 & 0 & 0 & -7 \\ 600 & -23 & 0 & -21 & -44 \\ 800 & -42 & 0 & -9 & -51 \\ 1.000 & -52 & 0 & -2 & -54 \\ 1,200 & -97 & 0 & -73 \\ 1,400 & -118 & 0 & 24 & -102 \\ \text { Unbounded } & -133 & 0 & 17 & -120\end{array}$

\section{$\underline{1995}$}

200

400

Unbounded

$\begin{aligned}-3 & -26 \\ 1 & -67 \\ 0 & -67\end{aligned}$

$-29$

$-63$

$-63$

Notes: - Sum of components may not equal total due to Independent rounding. O May Include changes in shipments from the West Coast to other PAD districts.

Source: TRIP mode1 solutions. 


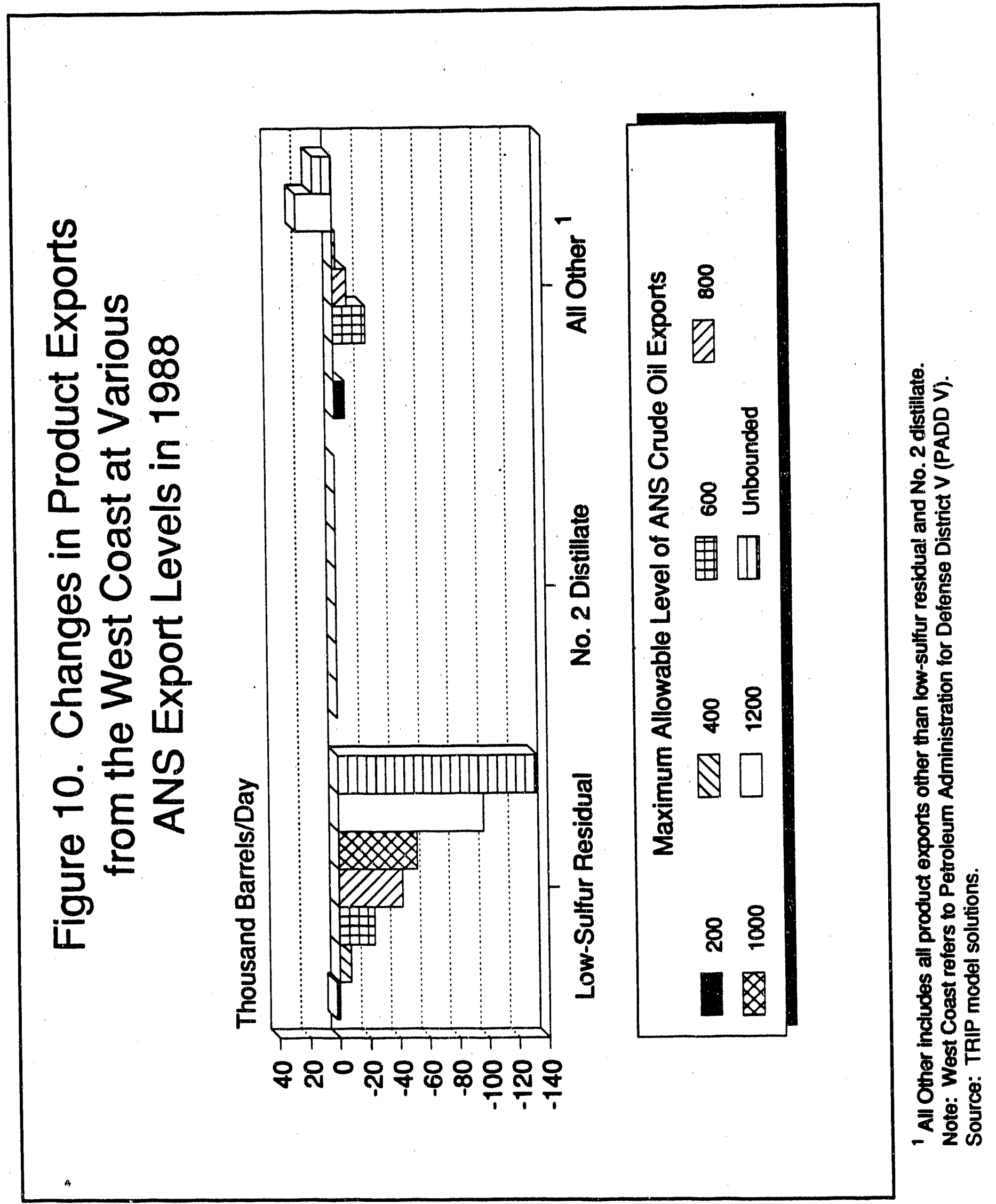




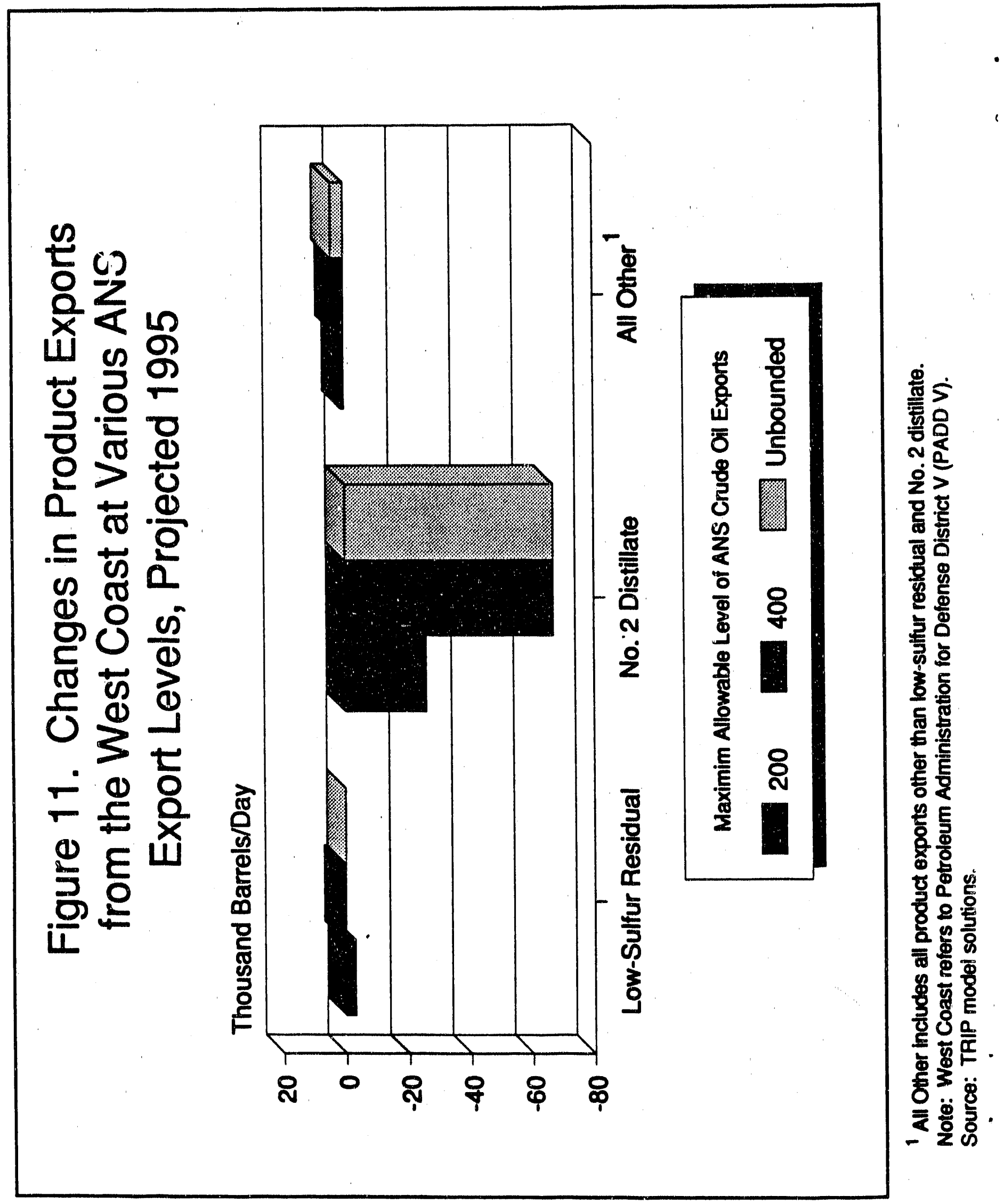


The price of ANS crude on the West Coast could increase if the ANS export ban were eliminated. The increase reflects the higher value placed on that crude by refiners in the Pacific Basin, since ANS crude is better sulted to produce the middle distillates that are in relatively great demand in that area than it is to produce gasoline on the West Coast. The Increase in the price of ANS crude would probably have been substantial if the ban had been eliminated in 1988. The increase is 11kely to be minimal if 1 t is 11fted in 1995, since the expected continued decrease in the production of Alaskan crude ofl w1ll already have resulted in a substantial price increase by that year. Product prices on the West Coast would not 11kely change substantially in elther year for two reasons. First, the crudes that would be Imported into the West Coast to compensate for the exports would be better suited to produce gasoline than is ANS crude. Refinery processing costs would therefore decrease. Second, the existing unconstrained trade in petroleum products places effective limits on product price increases.

The effects on West Coast crude and product flows that could result from eliminating the ban are summarized in Table 14. By assumption, crude ofl production in any given year is not affected by the increase in ANS or other crude oll prices, and product demand 18 also fixed at the base case (no ANS crude ofl exports) level. The total amount of crude ofl avallable to the West Coast remains constant in any given year as crude oll imports increase to compensate for the ANS volumes exported. West Coast product imports and exports both decline. The decrease in product Imports reflects the increased West Coast refinery production of gasoline as more sultable crudes are imported. The decrease in product exports reflects the decrease in West Coast production of residual and distilate fuels as more gasoline is produced. 
Table 14. Petroleum Supply and Demand Balances on the West Coast at Varlous ANS Export Levels, 1988 and 1995

(Thousand Barrels per Day)

\begin{tabular}{|c|c|c|c|c|c|c|c|}
\hline \multirow[b]{2}{*}{ Supp1y/Demand } & \multicolumn{5}{|c|}{ Maximum Allowable Level of ANS } & \multicolumn{2}{|c|}{ O11 Exports } \\
\hline & $\begin{array}{l}\text { Ful1 } \\
\text { Ban }\end{array}$ & $\begin{array}{l}400 \\
\mathrm{MB} / \mathrm{d}\end{array}$ & $\begin{array}{l}800 \\
\mathrm{MB} / \mathrm{d}\end{array}$ & $\begin{array}{l}\text { No } \\
\text { Ban }\end{array}$ & $\begin{array}{l}\text { Fu11 } \\
\text { Ban }\end{array}$ & $\begin{array}{l}400 \\
\mathrm{MB} / \mathrm{d}\end{array}$ & $\begin{array}{l}\text { No } \\
\text { Ban }\end{array}$ \\
\hline & \multicolumn{4}{|c|}{1988} & \multicolumn{3}{|c|}{1995} \\
\hline $\begin{array}{l}\text { Supply: } \\
\text { Crude Productipn }{ }^{a} \\
\text { Imported Crude }{ }^{c} \\
\text { Exported Crude } \\
\text { Imported Product } \\
\text { Exported Product } \\
\text { Refinery Galn } \\
\text { Stock Draw } \\
\text { Total Supply }\end{array}$ & $\begin{array}{r}3,164 \\
225 \\
689 \\
405 \\
526 \\
162 \\
13 \\
2,754\end{array}$ & $\begin{array}{r}3,164 \\
225 \\
689 \\
398 \\
520 \\
163 \\
13 \\
2,754\end{array}$ & $\begin{array}{r}3,164 \\
415 \\
879 \\
350 \\
475 \\
166 \\
13 \\
2,754\end{array}$ & $\begin{array}{r}3,164 \\
1,140 \\
1,604 \\
276 \\
406 \\
171 \\
\quad 13 \\
2,754\end{array}$ & $\begin{array}{r}2,259 \\
916 \\
25 \\
161 \\
643 \\
178 \\
2 \\
2,847\end{array}$ & $\begin{array}{r}2,259 \\
1,316 \\
425 \\
95 \\
580 \\
181 \\
2 \\
2,847\end{array}$ & $\begin{array}{r}2,259 \\
1,322 \\
431 \\
95 \\
580 \\
181 \\
\quad 2 \\
2,847\end{array}$ \\
\hline $\begin{array}{l}\text { Demand: } \\
\text { Gasoline } \\
\text { Distillate } \\
\text { Residual } \\
\text { Jet Fuel } \\
\text { LPG's } \\
\text { Other Products } \\
\text { Crude 011 } \\
\text { Total Demand }\end{array}$ & $\begin{array}{r}1,253 \\
423 \\
268 \\
404 \\
79 \\
287 \\
40 \\
2,754\end{array}$ & $\begin{array}{r}1,253 \\
423 \\
268 \\
404 \\
79 \\
287 \\
40 \\
2,754\end{array}$ & $\begin{array}{r}1,253 \\
423 \\
268 \\
404 \\
79 \\
287 \\
40 \\
2,754\end{array}$ & $\begin{array}{r}1,253 \\
423 \\
268 \\
404 \\
79 \\
287 \\
\quad 40 \\
2,754\end{array}$ & $\begin{array}{r}1,284 \\
446 \\
286 \\
424 \\
89 \\
319 \\
0 \\
2,847\end{array}$ & $\begin{array}{r}1,284 \\
446 \\
286 \\
424 \\
89 \\
319 \\
0 \\
2,847\end{array}$ & $\begin{array}{r}1,284 \\
446 \\
286 \\
424 \\
89 \\
319 \\
0 \\
2,847\end{array}$ \\
\hline
\end{tabular}

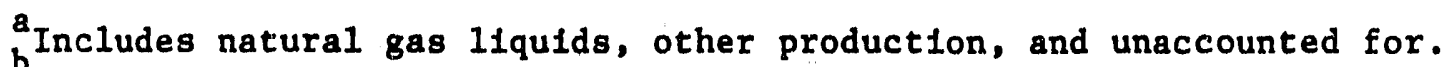
bhipments into the West Coast from other domestic reglons and from fore1gn countries.

Shlpments from the West Coast to other domest1c regtons and to forelgn countries.

Note: Sum of components may not equal total due to independent rounding. Source: TRIP model solutions. 


\section{LIMITATIONS AND QUALIFICATIONS}

There is uncertalnty concerning the actual effects that would occur if the ban on Alaskan crude ofl were ellminated. No model can be expected to preclsely capture all of the behavioral reactions and technological adfustments that would ensue. The best that can be expected is an indication of the direction and general order of magnitude of those effects. The results presented in this study should be viewed in that 11 ght rather than as highly accurate point estimates.

The uncertainty concerning the magnitude of the effects results, In large part, from 1imltations of the TRIP model and the assumptions made. Thxee that are integral to the model are particularly noteworthy. They relate to Instantaneous adfustment, feedback effects, and refinery aggregation.

The first of these model limitations relates to the speed of adfustment. The effects of eliminating the ban are instantaneously transmitted throughout much of the petroleum economy. The effects assoclated with unconstralned ANS export levels may therefore be overstated, at least for 1988 where the unconstrained level is large. To account for this limitation, the volume of ANS crude oll exports was constralned at varlous levels to provide a range of uncertainty and to analyze the sensitivities to alternative export levels.

The second model limitation relates to feedback effects. In reality, developments in the petroleum economy impact on other energy and nonenergy sectors, which in turn affect the petroleum economy. The model does not capture these feedback effects since petroleum 1s essentlally the only energy resource sector in the model. These feedback effects would probably be small during the years in which the ban is eliminated.

A third limitation that is integral to the model relates to the aggregation of refinerles. The model consists of 33 world reglons, each of which 1s represented by a single refinery. This is a great simplification of reality. For example, the West Coast region contains about 50 refineries, and a single representation of those refinerles may lead to different results than would occur in the real world. Due to this 11mitation, the magnitude of the price effects are subject to considerably more uncertainty than are the crude volume effects.

Many of the additional IImitations relate to the assumptions incorporated into the model rather than to the model 1tself. For example, the volume of ANS crude o1. production is set at the level forecasted with the ban in effect. The level is not altered to reflect the likely increase in production that would occur in reaction to higher prices if the ban were eliminated. It is estimated that any increase in production would be small during the year the ban is 
eliminated. Further, sensitivity analysis indlcates that any such increase in production would be exported, with few additional effects. In particular, there would be Ilttle further change in elther the price of ANS crude on the West Coast or in the compensating volume of crude oll imported into that region.

Final product demand 1 n each of the world's 33 refinery reglons 18 assumed to be Invarlant with respect to any given level of ANS exports during the year in which the ban 18 eliminated. In reality, product demand should respond to the ensulng change in product prices. Since the relative and absolute changes in product prices are small (about 1 cent per gallon or less), the potential effects on the level and composition of product demand are probably also smal1. (Although the level and composition of product demand are fixed for any glven year, they are set at different levels in 1988 and 1995.)

A major assumption is that refinexy capacity in each region is the same in 1995 as in 1988. As a result, 1995 capacity utilization is generally at 100 percent in U.S. refinary reglons and at or near 100 percent in most other regions. The almost complete capacity utilization reflects not only the fixed capacity assumption but also the assumptions that final product demand and crude oll production w1ll both be greater In 1995 than in 1988. As a result, model-generated ANS crude exports and petroleum product Imports into the U.S. West Coast in 1995 are probably greater than they would be if capacity were greater. However, the constraint on capasity is not entiraly unrealistic since there w11l 11kely be little growth In capac1ty, at least in the Untted States, to 1925. The constraint on capactty within the model probably caused product prices to be slightly higher than they would otherwlse be in that year, while putting downward pressure on crude prices.

Ocean transportation costs add significantly to the delivered price of crude petroleum and products. Generally, it was assumed that these costs were the same (In constant 1988 dollars) In 1995 as in 1988. The one exception 1s that the bunker fuel component of the costs was changed for 1995. The assumption of essentially constant transportation costs probably understates the costs that w11l actually exist in 1995 and, therefore, the delivered price of much of the o1l sold on world markets. The reason 18 that substantlal increases in production by members of the Organization of Petroleum Exporting Countries (OPEC) are expected by that year, and the assoclated Increase in demand for tanker services could cause transportation rates to rise.

The net effect of these limitations and qualifications on the results generated by the TRIP model 18 probably not great. Although the effects of Iffing the export ban would undoubtedly differ somewhat from those presented here, the general order of magnitude of the estimated effects are considered representative of actual energy markets. 

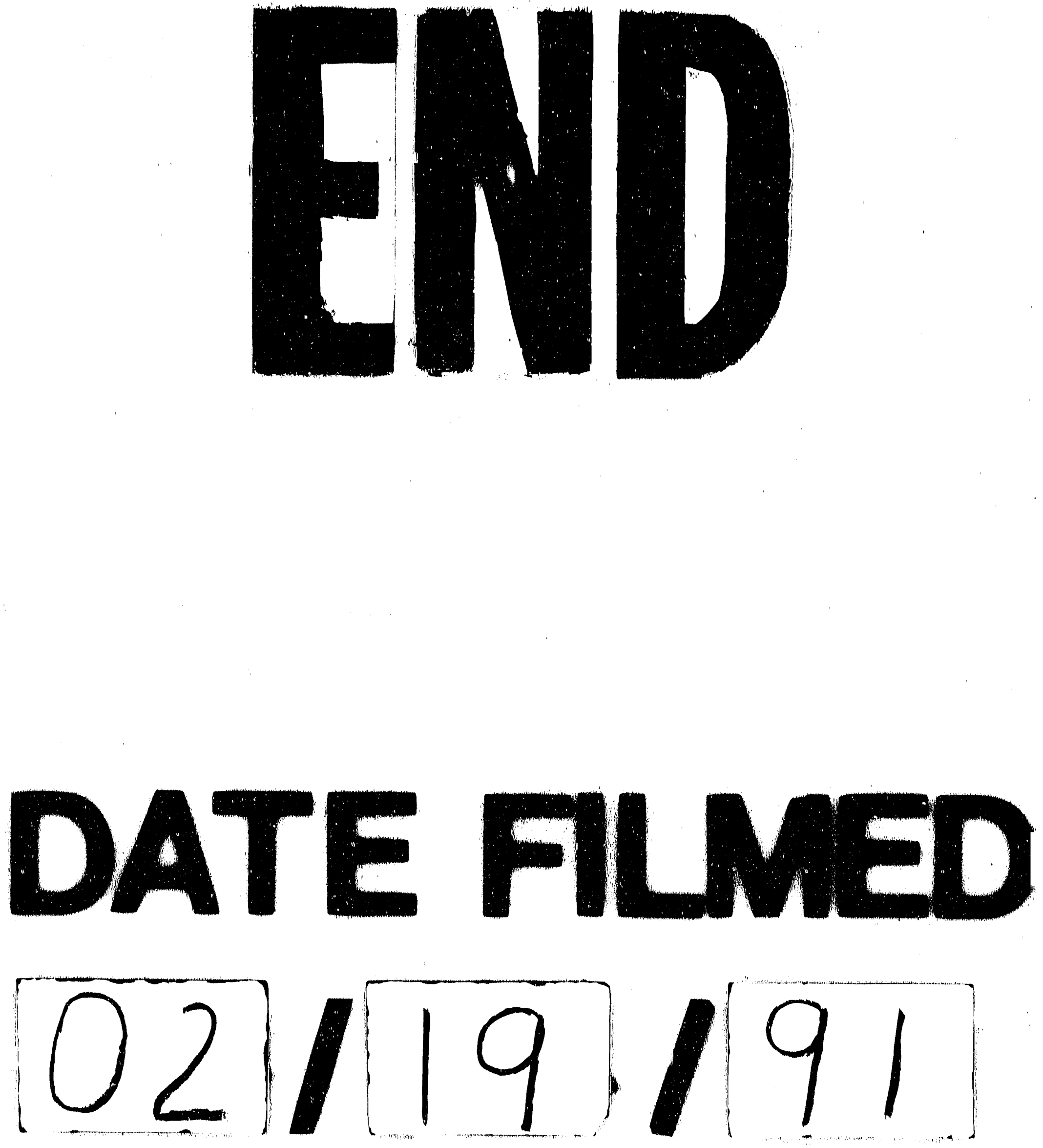
